\title{
Size-resolved measurements of ice-nucleating particles at six locations in North America and one in Europe
}

\author{
R. H. Mason ${ }^{1}$, M. Si ${ }^{1}$, C. Chou ${ }^{1}$, V. E. Irish ${ }^{1}$, R. Dickie ${ }^{1}$, P. Elizondo ${ }^{1}$, R. Wong ${ }^{1}$, M. Brintnell ${ }^{2}$, M. Elsasser ${ }^{2}$, \\ W. M. Lassar ${ }^{3}$, K. M. Pierce ${ }^{3}$, W. R. Leaitch ${ }^{2}$, A. M. MacDonald ${ }^{4}$, A. Platt ${ }^{2}$, D. Toom-Sauntry ${ }^{2}$, R. Sarda-Estève ${ }^{5}$, \\ C. L. Schiller ${ }^{6}$, K. J. Suski ${ }^{7}$, T. C. J. Hill ${ }^{7}$, J. P. D. Abbatt ${ }^{8}$, J. A. Huffman ${ }^{3}$, P. J. DeMott ${ }^{7}$, and A. K. Bertram ${ }^{1}$ \\ ${ }^{1}$ Department of Chemistry, University of British Columbia, Vancouver, BC, V6T1Z1, Canada \\ ${ }^{2}$ Climate Research Division, Environment Canada, Toronto, ON, M3H5T4, Canada \\ ${ }^{3}$ Department of Chemistry and Biochemistry, University of Denver, Denver, CO, 80208, USA \\ ${ }^{4}$ Air Quality and Processes Research Section, Environment Canada, Toronto, ON, M3H5T4, Canada \\ ${ }^{5}$ Laboratoire des Sciences du Climat et de l'Environnement, CEA/CNRS-UVSQ, 91191, Gif/Yvette, France \\ ${ }^{6}$ Air Quality Science Unit, Environment Canada, Vancouver, BC, V6C3S5, Canada \\ ${ }^{7}$ Department of Atmospheric Sciences, Colorado State University, Fort Collins, CO, 80523, USA \\ ${ }^{8}$ Department of Chemistry, University of Toronto, Toronto, ON, M5S3H6, Canada
}

Correspondence to: A. K. Bertram (bertram@chem.ubc.ca)

Received: 8 July 2015 - Published in Atmos. Chem. Phys. Discuss.: 29 July 2015

Revised: 23 January 2016 - Accepted: 26 January 2016 - Published: 11 February 2016

\begin{abstract}
Detailed information on the size of ice-nucleating particles (INPs) may be useful in source identification, modeling their transport in the atmosphere to improve climate predictions, and determining how effectively or ineffectively instrumentation used for quantifying INPs in the atmosphere captures the full INP population. In this study we report immersion-mode INP number concentrations as a function of size at six ground sites in North America and one in Europe using the micro-orifice uniform-deposit impactor droplet freezing technique (MOUDI-DFT), which combines particle size-segregation by inertial impaction and a microscopebased immersion freezing apparatus. The lowest INP number concentrations were observed at Arctic and alpine locations and the highest at suburban and agricultural locations, consistent with previous studies of INP concentrations in similar environments. We found that $91 \pm 9,79 \pm 17$, and $63 \pm 21 \%$ of INPs had an aerodynamic diameter $>1 \mu \mathrm{m}$ at ice activation temperatures of $-15,-20$, and $-25^{\circ} \mathrm{C}$, respectively, when averaging over all sampling locations. In addition, $62 \pm 20$, $55 \pm 18$, and $42 \pm 17 \%$ of INPs were in the coarse mode $(>2.5 \mu \mathrm{m})$ at ice activation temperatures of $-15,-20$, and $-25^{\circ} \mathrm{C}$, respectively, when averaging over all sampling locations. These results are consistent with six out of the nine studies in the literature that have focused on the size distribu-
\end{abstract}

tion of INPs in the atmosphere. Taken together, these findings strongly suggest that supermicron and coarse-mode aerosol particles are a significant component of the INP population in many different ground-level environments. Further sizeresolved studies of INPs as a function of altitude are required since the size distribution of INPs may be different at high altitudes due to size-dependent removal processes of atmospheric particles.

\section{Introduction}

Ice-nucleating particles (INPs) are a unique class of aerosol particles that catalyze ice formation under atmospheric conditions. A variety of particle types have been identified as INPs, including mineral dust, black carbon, volcanic ash, glassy aerosols, and primary biological particles such as bacteria, fungal spores, and pollen (see reviews by Szyrmer and Zawadzki, 1997; Möhler et al., 2007; Ariya et al., 2009; Després et al., 2012; Hoose and Möhler, 2012; Murray et al., 2012; Yakobi-Hancock et al., 2013). Although only a small fraction of aerosol particles nucleate ice (e.g., Rogers et al., 1998), INPs are important since they can lead to changes in the properties and lifetimes of mixed-phase and ice clouds, 
ultimately affecting climate and precipitation (Baker, 1997; Lohmann and Feichter, 2005; Baker and Peter, 2008; DeMott et al., 2010; Creamean et al., 2013).

Vali et al. (2015) describes four modes of heterogeneous ice nucleation: deposition nucleation, where ice forms on the INP directly from the gas phase; condensation freezing, where ice nucleates during the condensing of water onto the INP; immersion freezing, where crystallization is initiated by an INP within a supercooled liquid droplet; and contact freezing, where the freezing of a supercooled liquid droplet is due to impaction by an INP. In this study we focus on freezing via the immersion mode in dilute solution droplets, which is relevant to mixed-phase cloud conditions.

Due to the importance of INPs for climate and precipitation, there has been a renewed interest in measuring the concentrations of INPs in the atmosphere (DeMott et al., 2011). While much of this work has focused on measurements of the total number concentration of INPs, there has been less emphasis on determining their size distributions in the atmosphere. Information on airborne INP size distributions may be particularly helpful in identifying the predominant INP sources. For example, information on the size distribution of INPs may help rule out or support the role of fungal spores in atmospheric ice nucleation since they are often in the supermicron range (Graham et al., 2003; Elbert et al., 2007; Sesartic and Dallafior, 2011; Després et al., 2012; Huffman et al., 2012). A similar approach can be used with black carbon particles, since they are mainly in the submicron range (Clarke et al., 2004; Schwarz et al., 2008, 2013).

Previous modeling studies have shown that the transport and distribution of INPs, and aerosol particles in general, are sensitive to the size of the particles assumed in the models (Burrows et al., 2009; Wilkinson et al., 2011). Information on the size distributions of INPs are thus needed for accurate modeling of their transport and distributions in the atmosphere (Morris et al., 2004; Hoose et al., 2010a, b; Sesartic et al., 2013; Haga et al., 2014; Spracklen and Heald, 2014).

Information on the size distribution of INPs is also needed to determine whether techniques used to measure atmospheric INP concentrations capture the entire INP population. For example, the continuous flow diffusion chamber (Rogers et al., 2001b) is often used for measuring INPs (e.g., DeMott et al., 1998; Rogers et al., 2001a; Richardson et al., 2007; Pratt et al., 2009; Prenni et al., 2009; Eidhammer et al., 2010; Chou et al., 2011; Friedman et al., 2011; Hoyle et al., 2011; Corbin et al., 2012; Garcia et al., 2012; Tobo et al., 2013; McCluskey et al., 2014). This type of instrument has the advantage of providing real-time measurements of INPs with the ability to detect very large INP number concentrations, but the aerodynamic diameter of particles measured with it is limited, from $d_{50} \leq 2.4 \mu \mathrm{m}$ in some studies (e.g., Garcia et al., 2012) to $d_{50} \leq 0.75 \mu \mathrm{m}$ in others (e.g., DeMott et al., 2003). Such techniques may miss supermicron or coarse-mode (i.e., larger than $2.5 \mu \mathrm{m}$ ) INPs. The exact proportion of INPs missed may depend on temperature. Such online instruments have typically focused on measurements below approximately $-20^{\circ} \mathrm{C}$ as sample volume considerations limit effective sampling of lower INP number concentrations at warmer temperatures. The exact proportion of INPs missed may also depend on altitude since the removal of atmospheric particles by wet and dry deposition in the atmosphere is expected to be size dependent. As an example, supermicron particles have larger dry deposition loss rates than submicron particles.

Previous studies of INPs as a function of size have been carried out in the field (e.g., Vali, 1966; Rosinski et al., 1986; Mertes et al., 2007; Santachiara et al., 2010) and in the laboratory (e.g., Welti et al., 2009; O'Sullivan et al., 2015). These and additional studies are further discussed in Sect. 3.2. In the current study, we add to the existing body of size-resolved INP measurements by reporting ground-level INP size distributions from six locations in North America and one in Europe, covering a diverse set of environments and investigating immersion freezing at $-15,-20$, and $-25^{\circ} \mathrm{C}$.

\section{Methods}

\subsection{Sampling sites}

The seven locations used in this study are detailed in Table 1 and shown in Fig. 1. All reported sampling periods are local times. Measurements using the sampling instrumentation described in the next section were made at five locations in Canada: Alert, Nunavut; the Labrador Sea near Newfoundland and Labrador; Whistler Mountain, British Columbia; the University of British Columbia (UBC) campus, British Columbia; and Amphitrite Point, British Columbia. Measurements in Canada were conducted as part of the larger NETwork on Climate and Aerosols: addressing key uncertainties in Remote Canadian Environments project (NETCARE; http://netcare-project.ca/). Measurements were also made at Saclay, France and Colby, Kansas, USA.

\subsubsection{Alert}

Arctic sampling was conducted at the Dr. Neil Trivett Global Atmosphere Watch Observatory in Alert, Nunavut, Canada (labeled 1 in Fig. 1; Cobbett et al., 2007) between 29 March and 23 July 2014. This Arctic research station is part of a global network for measuring chemical and physical perturbations of the atmosphere. Aerosol particles were collected through a louvered total suspended particulate (TSP) inlet (Mesa Labs Inc., Butler, NJ, USA) and $0.9 \mathrm{~m}$ mast located on the upper level of an outdoor platform free of surrounding obstructions, and were stored in the dark at -15 or $4{ }^{\circ} \mathrm{C}$ for a period of 10-112 days prior to analysis. 
Table 1. The seven locations used in this study and conditions during sampling.

\begin{tabular}{|c|c|c|c|c|c|c|c|c|c|}
\hline Location & Environment & Coordinates & $\begin{array}{r}\text { Elevation } \\
(\mathrm{m})\end{array}$ & $\begin{array}{r}\text { Sampling } \\
\text { period }\end{array}$ & $\begin{array}{r}\text { Number } \\
\text { of samples }\end{array}$ & $\begin{array}{r}\text { Average sampling } \\
\text { time (h) }\end{array}$ & $\begin{array}{r}\text { Average } \\
\text { temperature }\left({ }^{\circ} \mathrm{C}\right)\end{array}$ & $\begin{array}{r}\text { Average relative } \\
\text { humidity }(\%)\end{array}$ & $\begin{array}{l}\text { Particle size } \\
\text { range }(\mu \mathrm{m})^{\mathrm{a}}\end{array}$ \\
\hline $\begin{array}{l}\text { Alert, NU, } \\
\text { Canada }\end{array}$ & Arctic & $\begin{array}{l}82.45^{\circ} \mathrm{N} \\
62.51^{\circ} \mathrm{W}\end{array}$ & $\begin{array}{l}12 \text { a.g.1. } \\
200 \text { a.s.l. }\end{array}$ & $\begin{array}{r}\text { Mar. 29-Jul. 23, } \\
2014\end{array}$ & 9 & 18 & -17.4 & 77 & $0.10-10$ \\
\hline $\begin{array}{l}\text { Whistler Mountain, } \\
\text { BC, Canada }\end{array}$ & Alpine & $\begin{array}{r}50.06^{\circ} \mathrm{N} \\
122.96^{\circ} \mathrm{W}\end{array}$ & $\begin{array}{r}2 \text { a.g.l. } \\
2182 \text { a.s.l. }\end{array}$ & $\begin{array}{r}\text { Mar. 30-Apr. 23, } \\
2014\end{array}$ & 4 & 6.7 & -0.8 & 83 & $0.18-10$ \\
\hline $\begin{array}{l}\text { Amphitrite Point, } \\
\text { BC, Canada }\end{array}$ & Coastal & $\begin{array}{r}48.92^{\circ} \mathrm{N} \\
125.54^{\circ} \mathrm{W}\end{array}$ & $\begin{array}{r}5.5 \text { a.g.l. } \\
25 \text { a.s.l. }\end{array}$ & $\begin{array}{r}\text { Aug. 6-27, } \\
2013\end{array}$ & 34 & 7.8 & 13.8 & 97 & $0.18-10$ \\
\hline $\begin{array}{l}\text { The Labrador Sea, } \\
\text { Canada }\end{array}$ & Marine & $\begin{array}{r}54.50^{\circ} \mathrm{N} \\
55.37^{\circ} \mathrm{W}\end{array}$ & $\begin{array}{l}2 \text { a.g.l. } \\
15 \text { a.s.l. }\end{array}$ & $\begin{array}{r}\text { Jul. } 11, \\
2014\end{array}$ & 1 & 6.2 & 10.9 & 75 & $0.10-10$ \\
\hline $\begin{array}{l}\text { CEA, Saclay, } \\
\text { France }\end{array}$ & Suburban & $\begin{array}{r}48.70^{\circ} \mathrm{N} \\
2.14^{\circ} \mathrm{E}\end{array}$ & $\begin{array}{l}10 \text { a.g.1. } \\
168 \text { a.s.l. }\end{array}$ & $\begin{array}{r}\text { Jul. 15-Aug. } 4 \text {, } \\
2014\end{array}$ & 15 & 7.2 & 20.6 & 69 & $0.10-10$ \\
\hline $\begin{array}{l}\text { UBC campus, } \\
\text { BC, Canada }\end{array}$ & Suburban & $\begin{array}{r}49.26^{\circ} \mathrm{N} \\
123.25^{\circ} \mathrm{W}\end{array}$ & $\begin{array}{l}24 \text { a.g.l. } \\
120 \text { a.s.l. }\end{array}$ & $\begin{array}{r}\text { May } 12-16, \\
2014\end{array}$ & 4 & 6.3 & 15.2 & 70 & $0.10-10$ \\
\hline $\begin{array}{l}\text { Colby, } \\
\text { KS, USA }\end{array}$ & Agricultural & $\begin{array}{r}39.39^{\circ} \mathrm{N} \\
101.06^{\circ} \mathrm{W} \\
\text { and } 39.39^{\circ} \mathrm{N} \\
101.08^{\circ} \mathrm{W}\end{array}$ & $\begin{array}{r}2 \text { a.g.1. } \\
968 \text { a.s.1. }\end{array}$ & $\begin{array}{r}\text { Oct. } 14-15, \\
2014\end{array}$ & 3 & 4.5 & 17.0 & 48 & $0.10-10$ \\
\hline
\end{tabular}

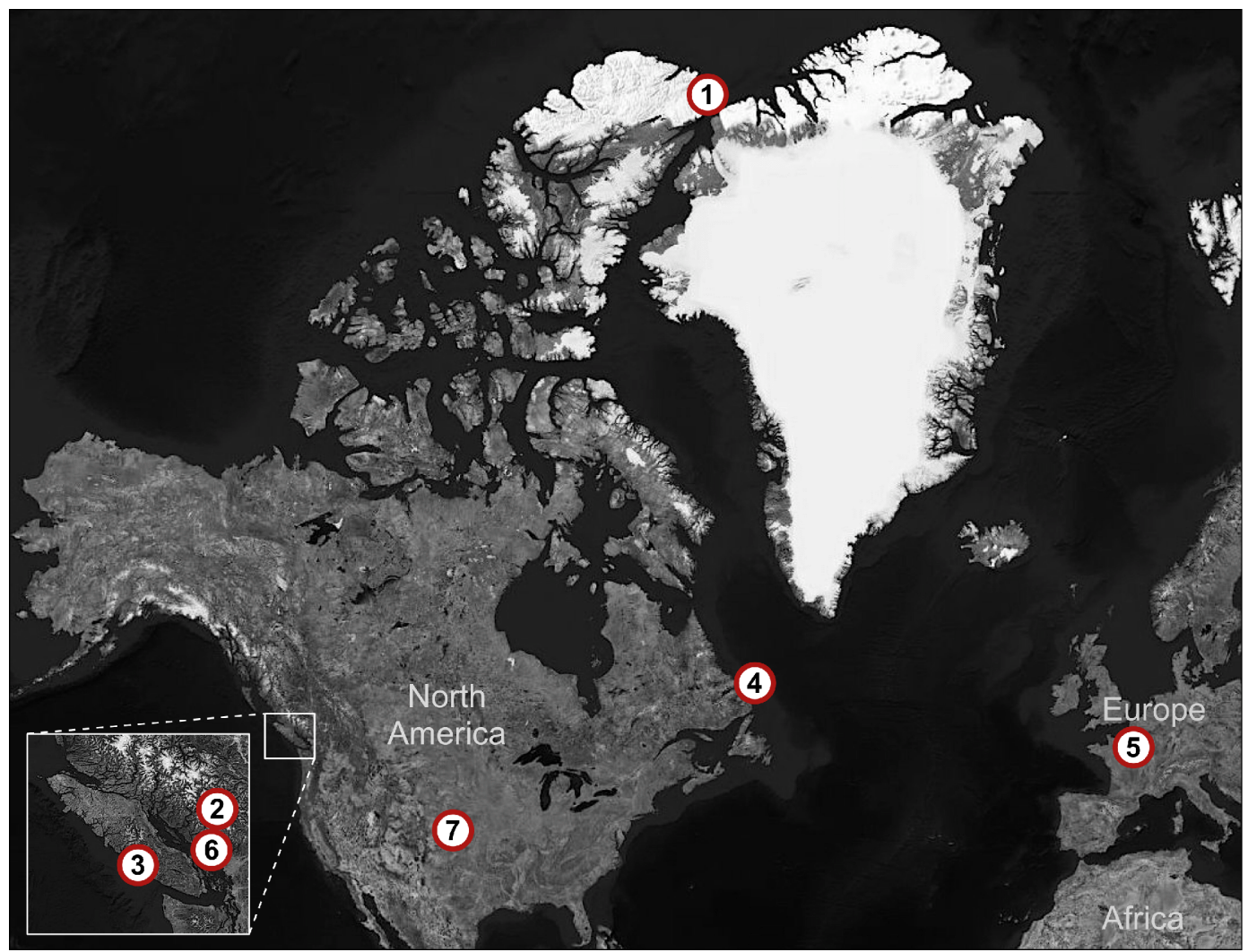

Figure 1. Sampling locations used in this study: (1) Alert, Nunavut, Canada; (2) Whistler Mountain, British Columbia, Canada; (3) Amphitrite Point, British Columbia, Canada; (4) the Labrador Sea, Canada; (5) CEA in Saclay, France; (6) the University of British Columbia campus, British Columbia, Canada; and (7) Colby, Kansas, USA. Site coordinates are given in Table 1 with details in Sect. 2.1. The image was modified from Bing Maps, 2014 (http://bing.com/maps).

\subsubsection{Whistler Mountain}

The Whistler Peak High Elevation Site is located at the summit of Whistler Mountain in Whistler, British Columbia, Canada (labeled 2 in Fig. 1) and operated by Environment Canada (Gallagher et al., 2011; Macdonald et al., 2011).
Aerosol particle collection at this alpine site occurred between 30 March and 23 April 2014. The louvered TSP inlet was located approximately $10 \mathrm{~m}$ from a chairlift operating station. Although there are no continuous combustion sources at the site, sampled air may have been influenced by engine exhaust for short periods of time due to nearby snow- 
mobile operation. Samples were stored in the dark at $4{ }^{\circ} \mathrm{C}$ for a period of 1-4 days prior to analysis.

\subsubsection{Amphitrite Point}

The coastal site at Amphitrite Point on Vancouver Island, British Columbia, Canada (labeled 3 in Fig. 1) is operated by Environment Canada, the BC Ministry of Environment, and Metro Vancouver for the continuous monitoring of aerosols and trace gases influenced by marine trajectories (McKendry et al., 2014; Yakobi-Hancock et al., 2014; Mason et al., 2015b). The mobile laboratory used during sampling was located approximately $100 \mathrm{~m}$ from the high tide line of the Pacific Ocean along a rocky shoreline, separated from the ocean by a narrow row of trees and shrubs approximately 2-10 $\mathrm{m}$ in height. Sampling took place from 6 to 27 August 2013 using a louvered TSP inlet and $3 \mathrm{~m}$ mast. Aerosol particles were stored at room temperature and analyzed within 1 day of collection.

\subsubsection{The Labrador Sea}

The Canadian Coast Guard Service vessel CCGS Amundsen serves as both an icebreaker for shipping lanes and an Arctic research vessel. One set of aerosol particle samples was collected from the top of the bridge of this vessel on July 11, 2014 while in the Labrador Sea off the coast of Newfoundland and Labrador, Canada (labeled 4 in Fig. 1). While sampling was within the marine boundary layer in the presence of sea spray aerosols, back trajectories (not included) calculated using the Hybrid Single-Particle Lagrangian Integrated Trajectory (HYSPLIT4) model of the National Oceanographic and Atmospheric Administration (Draxler and Rolph, 2014) indicate that the sampled air mass spent the majority of the previous $72 \mathrm{~h}$ period over land. Air was passed through a louvered TSP inlet and $1.5 \mathrm{~m}$ mast during sampling, and collected aerosol particles were stored in the dark at $4{ }^{\circ} \mathrm{C}$ for a period of 45-46 days prior to analysis.

\subsubsection{Saclay, France}

Aerosol particle samples were collected at the Commissariat à l'Energie Atomique (CEA) Atmospheric Supersite (AS), CEA l'Orme des Merisiers. The CEA-AS Observatory is a suburban area located $30 \mathrm{~km}$ southeast of Paris in Saclay, France (labeled 5 in Fig. 1). The CEA-AS Observatory is surrounded by different sources of bioaerosols such as forest and agricultural fields, and is often influenced by marine or urban air masses (Baisnée et al., 2014). Measurements were made as part of the BIODETECT 2014 intensive campaign, an intercomparison of bioaerosol detection methods (SardaEstève et al., 2014). During this study period, the site was heavily influenced by urban outflow. A large set of ancillary measurements was done to constrain all the particulate matter sources. Aerosol particles were sampled through a TSP inlet and $10 \mathrm{~m}$ mast between 15 July and 4 August 2014, and were stored in the dark at $4{ }^{\circ} \mathrm{C}$ for a period of 55-217 days prior to analysis.

\subsubsection{UBC campus}

Four sets of aerosol particle samples were collected from a weather station on the roof of the five-story Earth Sciences Building on the UBC campus in British Columbia, Canada (labeled 6 in Fig. 1). The UBC campus is located on a peninsula and is surrounded by forest on three sides and ocean on the fourth. The site has been classified as suburban since it is less than $10 \mathrm{~km}$ from downtown Vancouver. Samples were collected through a TSP inlet and $0.5 \mathrm{~m}$ mast between 12 and 16 May 2014. The aerosol particles were stored in the dark at $4{ }^{\circ} \mathrm{C}$ for a period of $21-23$ days prior to analysis.

\subsubsection{Colby, KS}

Aerosol particles were collected at the soybean and sorghum fields of the Kansas State University Northwest Research Center in Colby, KS, USA (labeled 7 in Fig. 1). One sample was collected at each location during combine harvesting from a distance approximately 3-10 $\mathrm{m}$ downwind of the field. A third sample was also collected at the sorghum field the night following harvest. Sampling took place on 14 and 15 October 2014 and samples were stored in the dark at $4{ }^{\circ} \mathrm{C}$ for a period of 41-46 days prior to analysis.

\subsection{Size-resolved INP number concentrations}

INP number concentrations as a function of size and temperature were determined using the micro-orifice uniformdeposit impactor droplet freezing technique (MOUDI-DFT; Huffman et al., 2013; Mason et al., 2015a). This technique combines aerosol particle collection by a cascade inertial impactor with sharp size-cutoff characteristics (the MOUDI; Marple et al., 1991) with an established droplet freezing apparatus (the DFT) for determining immersion-mode freezing properties (Koop et al., 1998; Iannone et al., 2011; Haga et al., 2013). A similar approach has also been used to study deposition nucleation by particles collected from the atmosphere (Wang et al., 2012; Knopf et al., 2014).

\subsubsection{Aerosol particle sampling}

Size-fractionated aerosol particle samples were collected onto hydrophobic glass cover slips (HR3-215; Hampton Research, Aliso Viejo, CA, USA) using a model 110R or 120R MOUDI (MSP Corp., Shoreview, MN, USA). Previous work has shown that these hydrophobic glass surfaces do not cause significant heterogeneous ice nucleation (e.g., Haga et al., 2013, 2014; Wheeler et al., 2015). Substrate holders were used on the impaction plates of the MOUDI to reproducibly position the hydrophobic glass cover slips in regions where aerosol deposit particle concentrations did not vary significantly (for details see Mason et al., 2015a). At most loca- 
tions MOUDI stages 2-9 were used, corresponding to particle size bins of 10-5.6, 5.6-3.2, 3.2-1.8, 1.8-1.0, 1.0-0.56, $0.56-0.32,0.32-0.18$, and $0.18-0.10 \mu \mathrm{m}$ (50\% cutoff aerodynamic diameter; Marple et al., 1991), respectively. The range in particle size collected at each location is given in Table 1.

Bounce within inertial impactors such as the MOUDI can occur during aerosol sampling, where particles impact the collection substrate but are not retained. This rebounding of particles from the surface could possibly alter the INP number concentrations and size distributions being measured. If composition is held constant, bounce is expected to increase with particle size because of their greater kinetic energy (Dahneke, 1971). Hence, INP number concentrations for large particle sizes may be underestimated here. Bounce is also expected to increase with decreasing relative humidity $(\mathrm{RH})$. Previous work has shown that having a sample $\mathrm{RH}$ of $70 \%$ or greater can be effective in reducing particle bounce (e.g., Winkler, 1974; Fang et al., 1991; Stein et al., 1994; Vasiliou et al., 1999; Chen et al., 2011; Bateman et al., 2014), although its efficacy is dependent on particle type (Winkler, 1974; Lawson, 1980; Saukko et al., 2012). For six out of the seven sites investigated here, the average RH during sampling was $69 \%$ or greater. Recently, results from the MOUDI-DFT and the continuous flow diffusion chamber were compared during an ambient field campaign at Colorado State University (Mason et al., 2015a). For particle sizes $<2.4 \mu \mathrm{m}$, the INP number concentrations measured by the MOUDI-DFT were within experimental error of those measured by the continuous flow diffusion chamber technique, suggesting that bounce was not an issue during these previous ambient field measurements. Based on these previous measurements, in the current studies we do not consider the issue of particle bounce when calculating INP number concentrations and size distributions. Nevertheless, additional studies are warranted to better quantify the effect of bounce.

During sampling, the aerosols were not brought to a standardized humidity, and the RH varied from site-to-site (see Table 1 for the average RH during sampling at each site). This variability in RH could lead to a small variability in INP size due to differences in hygroscopic growth. We further note that the duration of sample storage varied in the current study. Additional studies are needed to quantify the effect of storage on INP activity.

\subsubsection{Freezing measurements}

Samples were analyzed by the DFT to determine the number concentration of particles active in the immersion-freezing mode. Details of the experimental procedure can be found in Mason et al. (2015a). Briefly, samples were transferred to a temperature- and humidity-controlled flow cell coupled to an optical microscope equipped with a $5 \times$ magnification objective (Axiolab; Zeiss, Oberkochen, Germany). Water droplets were condensed onto the sample and monitored using a CCD camera recording a digital video. Since the relative humidity of the gas flow during droplet condensation was held at approximately $120 \%$, water condensation occurred uniformly on the cover slip, and growing droplets coagulated as they grew to a final size of $97 \pm 42 \mu \mathrm{m}$ (mean diameter and 1 standard deviation (SD) uncertainty). The freezing temperature of each droplet was then determined during cooling at a rate of $-10{ }^{\circ} \mathrm{C} \mathrm{min}^{-1}$ using the video timestamp and a resistance temperature detector located within the flow cell. Note that droplet growth and coagulation occurs in the same manner for samples containing particles and clean hydrophobic glass cover slips (no particles deposited). In addition, based on an analysis of samples collected at Amphitrite Point, more than $99 \%$ of particles become incorporated into the droplets prior to the freezing experiments. Here we regard ice nucleation as a singular process (i.e., strictly temperature-dependent) but note that the stochastic (i.e., time-dependent) component to immersion freezing (Vali, 2014) may alter the median freezing temperature of a droplet by $0.5-2{ }^{\circ} \mathrm{C}$ per decade change in cooling rate (Murray et al., 2011; Welti et al., 2012; Wright and Petters, 2013; Wright et al., 2013; Wheeler et al., 2015).

A potential issue with the droplet freezing technique is heterogeneous ice nucleation initiated by the hydrophobic glass cover slips used to collect atmospheric particles. To address this issue, experiments were conducted using new hydrophobic glass cover slips that were processed in the same manner as ambient samples except they were not exposed to atmospheric particles drawn into the MOUDI. For the five hydrophobic glass cover slips investigated, which contained 231 droplets generated during the freezing experiments, the average freezing temperature was $-36.5 \pm 0.5^{\circ} \mathrm{C}(1 \mathrm{SD})$. In addition, none of the droplets froze above $-33.7^{\circ} \mathrm{C}$ in these blank experiments. Since we only report INP number concentrations for temperatures from -15 to $-25^{\circ} \mathrm{C}$ in this study, heterogeneous ice nucleation by the substrate is unlikely to contribute to the reported INP number concentrations.

\subsubsection{Calculating the number concentration of INPs}

The number of INPs in the DFT, \#INPs $(T)$, was calculated using the following equation which accounts for the possibility of a droplet containing multiple INPs (Vali, 1971):

$\# \operatorname{INPs}(T)=-\ln \left(\frac{N_{\mathrm{u}}(T)}{N_{\mathrm{o}}}\right) N_{\mathrm{o}} f_{\mathrm{nu}, 0.25-0.10 \mathrm{~mm}} f_{\mathrm{ne}}$

where $N_{\mathrm{u}}(T)$ is the number of unfrozen droplets at temperature $T, N_{\mathrm{o}}$ is the total number of droplets, $f_{\mathrm{nu}, 0.25-0.10 \mathrm{~mm}}$ is a non-uniformity correction factor that takes into account nonuniformity at the $0.25-0.10 \mathrm{~mm}$ scale, and $f_{\text {ne }}$ is a statistical uncertainty derived for a given number of detected nucleation events, with fewer nucleation events leading to greater statistical uncertainty (Koop et al., 1997). For the results reported, here $f_{\text {ne }}$ is derived for a confidence level of 0.95 . 
Equation (1) assumes that droplets in a given freezing experiment have the same volume (Vali, 1971). Using droplet freezing experiments reported in Mason et al. (2015a), which are similar to experiments presented here, we explored whether this assumption leads to uncertainties when applied to the DFT experiments. Number of INPs was first calculated from the DFT experiments as described above. Second, number of INPs were calculated by first separating the droplet freezing results into $2-4$ bins based on droplet volume. After binning the data by droplet volume, droplets in each bin are more similar in volume. Equation (1) was then used to calculate the number of INPs in each bin. Finally, the total number of INPs was determined by summing the numbers of INPs calculated for each bin. We found that the total number of INPs determined both ways (with and without binning) agreed within the experimental uncertainty at freezing temperatures of $-25^{\circ} \mathrm{C}$ and above for $97 \%$ of freezing events. We also analyzed the same data by first separating the droplet freezing results into 2-4 bins based on the maximum area the droplets covered. Again, the number of INPs determined with and without binning was in good agreement, being within the experimental uncertainty at freezing temperatures of $-25^{\circ} \mathrm{C}$ and above for $98 \%$ of freezing events. Based on this analysis we conclude that the application of Eq. (1), which assumes monodisperse droplets, to the DFT results at $-25^{\circ} \mathrm{C}$ and above does not lead to large uncertainties.

In the DFT, once a droplet freezes it may grow by vapor diffusion and contact a neighboring liquid droplet, causing the latter to freeze as well. To account for these nonimmersion freezing events, we calculated the $\# \operatorname{INPs}(T)$ in the immersion mode using two different scenarios: (i) we calculated an upper limit by assuming that all droplets which underwent the processes discussed above froze by immersion freezing; and (ii) we calculated a lower limit to the INP concentration by assuming that all droplets which underwent the processes discussed above remained liquid until the homogeneous freezing temperature of approximately $-37^{\circ} \mathrm{C}$ (Wheeler et al., 2015).

After $\# \operatorname{INPs}(T)$ were determined for a given freezing experiment, atmospheric INP number concentrations, $[\operatorname{INPs}(T)]$, were calculated using the following equation:

$[\operatorname{INPs}(T)]=\# \operatorname{INPs}(T)\left(\frac{A_{\text {deposit }}}{A_{\mathrm{DFT}} V}\right) f_{\mathrm{nu}, 1 \mathrm{~mm}}$,

where $A_{\text {deposit }}$ is the total area of the sample deposit on the MOUDI impaction plate, $A_{\mathrm{DFT}}$ is the area of the sample analyzed by the DFT $\left(1.2 \mathrm{~mm}^{2}\right.$ in all samples $), V$ is the volume of air sampled by the MOUDI, and $f_{\mathrm{nu}, 1 \mathrm{~mm}}$ is a correction factor to account for non-uniformity in particle concentration of the sample deposit at the $1 \mathrm{~mm}$ scale. See Mason

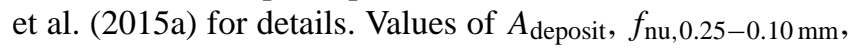
$f_{\text {nu, } 1 \mathrm{~mm}}$, and $f_{\text {ne }}$ are given in Tables $\mathrm{S} 1$ and $\mathrm{S} 2$ and discussed in Sect. S1 of the Supplement. Reported INP number concentrations at each location are averaged over all samples and have been adjusted to standard temperature and pressure. In

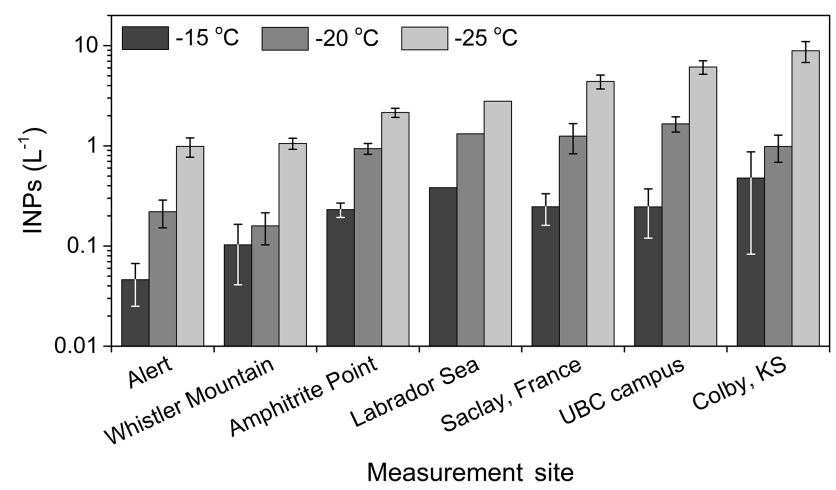

Figure 2. Mean INP number concentrations at droplet freezing temperatures of $-15^{\circ} \mathrm{C}$ (dark gray), $-20^{\circ} \mathrm{C}$ (intermediate gray), and $-25^{\circ} \mathrm{C}$ (light gray). Uncertainty is given as the standard error of the mean, assuming a normal distribution. As only one sample was available from the Labrador Sea, no uncertainty is reported.

calculating averages over all sampling locations, measurements have not been weighted by sample number.

For the experimental conditions used in the current study the maximum number concentration of INPs that could be detected was roughly $20 \mathrm{~L}^{-1}$. This maximum number concentration is greater than that reported in Huffman et al. (2013) because in the current studies shorter sampling times were used.

\section{Results and discussion}

\subsection{INP number concentrations}

The total number concentration of INPs active at $-15,-20$, and $-25^{\circ} \mathrm{C}$ are shown for each site in Fig. 2. Freezing events were rare at temperatures warmer than $-15^{\circ} \mathrm{C}$, accounting for only $1.3 \%$ of all cases, and are therefore not reported. Some of the DFT experiments proceeded such that all droplets froze at temperatures slightly below $-25^{\circ} \mathrm{C}$. Since this scenario prohibits calculation of INP number concentrations, $-25^{\circ} \mathrm{C}$ is the lowest temperature reported. As expected, INP number concentrations were found to increase with decreasing freezing temperature with the average concentration at $-25^{\circ} \mathrm{C}\left(3.8 \pm 2.9 \mathrm{~L}^{-1}\right)$ being more than an order of magnitude larger than at $-15^{\circ} \mathrm{C}\left(0.25 \pm 0.15 \mathrm{~L}^{-1}\right)$.

INP number concentrations were relatively low at the Alert and Whistler Mountain sites with values of 0.05 and $0.10 \mathrm{~L}^{-1}$ at $-15^{\circ} \mathrm{C}, 0.22$ and $0.16 \mathrm{~L}^{-1}$ at $-20^{\circ} \mathrm{C}$, and 0.99 and $1.1 \mathrm{~L}^{-1}$ at $-25^{\circ} \mathrm{C}$, respectively. These findings are consistent with previous measurements at similar locations. For example, Arctic measurements of Bigg (1996) for particles $<10 \mu \mathrm{m}$ and Fountain and Ohtake (1985) using filter samples found mean INP concentrations of $0.01 \mathrm{~L}^{-1}$ at $-15^{\circ} \mathrm{C}$ and $0.13 \mathrm{~L}^{-1}$ at $-20^{\circ} \mathrm{C}$, respectively, with both deposition and condensation modes likely possible, and Prenni et 
al. (2007) measured an average INP number concentration for particles with and aerodynamic diameter $<1.5 \mu \mathrm{m}$ of approximately $0.33 \mathrm{~L}^{-1}$ between -8 and $-28^{\circ} \mathrm{C}$ with deposition, condensation, and immersion modes likely possible. At high-elevation sites, Bowers et al. (2009) at Mt. Werner in Colorado and Conen et al. (2012) at the research station Jungfraujoch in Switzerland measured mean immersionmode INP number concentrations of approximately $0.02 \mathrm{~L}^{-1}$ at -10 and $-12{ }^{\circ} \mathrm{C}$, respectively, using filter samples of $0.2-$ $0.3 \mu \mathrm{m}$ pore size. High-elevation sites can receive large quantities of dust, which can act as efficient INPs at lower temperatures (Chou et al., 2011), but this was unlikely during our measurement period based on the low INP number concentrations.

INP number concentrations at Amphitrite Point were 0.23, 0.94 , and $2.15 \mathrm{~L}^{-1}$ at droplet freezing temperatures of -15 , -20 , and $-25^{\circ} \mathrm{C}$, respectively. Despite the predominance of marine air masses being sampled, the major source of INPs at Amphitrite Point during the study period was likely biological particles from local vegetation (Mason et al., 2015b). Similar values were measured in the Labrador Sea, where INP number concentrations at $-15,-20$, and $-25^{\circ} \mathrm{C}$ were $0.38,1.3$, and $2.8 \mathrm{~L}^{-1}$, respectively. These concentrations are consistent with previous measurements within the marine boundary layer in regions influenced by air flow off of nearby coasts, for instance those of Schnell (1977) in the immersion freezing mode for sizes $>0.45 \mu \mathrm{m}$ off the coast of Nova Scotia, roughly $1100-1500 \mathrm{~km}$ southwest of our sampling site in the Labrador Sea, and Rosinski et al. (1995) over the East China Sea in the deposition and condensation modes for sizes $>0.2 \mu \mathrm{m}$. However, INP number concentrations found during marine studies can vary by several orders of magnitude with changing location as summarized by Burrows et al. (2013).

The highest concentrations of INPs at a freezing temperature of $-25^{\circ} \mathrm{C}$ were found at the Colby sites, where the average number concentration was $8.9 \mathrm{~L}^{-1}$. Aerosol sampling was conducted adjacent to soya and sorghum fields during and following periods of combine operation. This high concentration of INPs is consistent with previous work of Garcia et al. (2012) that showed elevated concentrations of INPs downwind of corn fields during combine harvesting, and Bowers et al. (2011) who found greater INP concentrations in air above cropland than above suburban or forest sites.

The suburban sites of Saclay and the UBC campus also showed high INP concentrations, being 4.4 and $6.1 \mathrm{~L}^{-1}$, respectively, at a freezing temperature of $-25^{\circ} \mathrm{C}$. Both sites were likely influenced by multiple sources of INPs. For example, both are in close proximity to major metropolitan centers and forest vegetation, which are potential sources of anthropogenic INPs (e.g., Hobbs and Locatelli, 1970; Al-Naimi and Saunders, 1985; Knopf et al., 2010, 2014; Ebert et al., 2011; Corbin et al., 2012; Cziczo et al., 2013; Brooks et al., 2014) and biological INPs (e.g., Vali et al., 1976; Kieft and Ruscetti, 1990; Richard et al., 1996; Hirano and Upper,
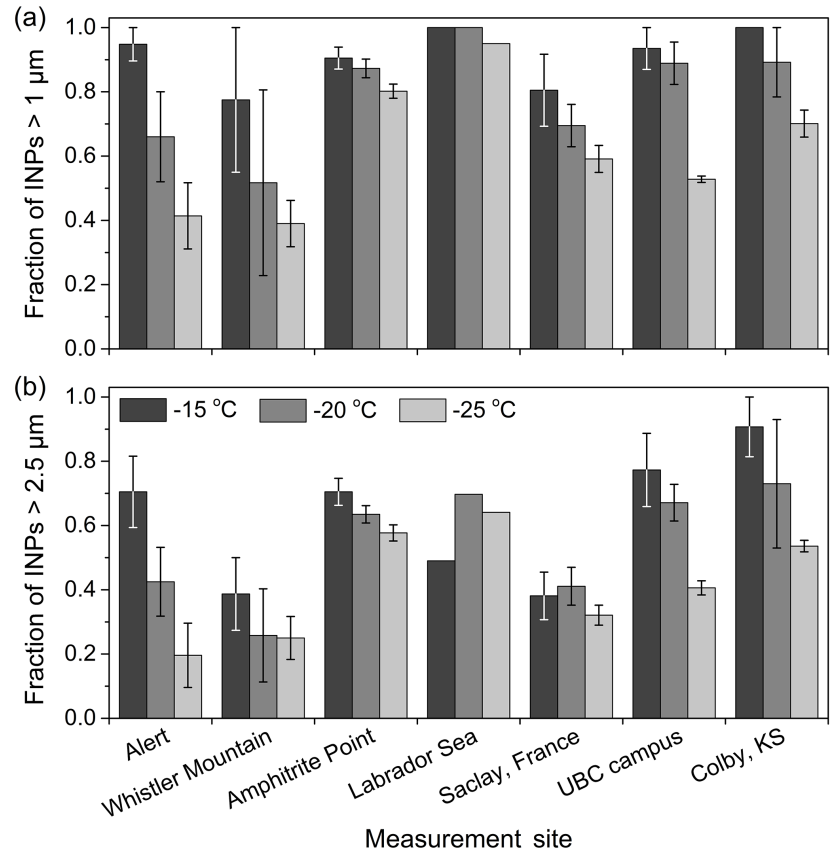

Figure 3. The mean fraction of INPs larger than (a) $1 \mu \mathrm{m}$ and (b) $2.5 \mu \mathrm{m}$. Uncertainty is the standard error of the mean, assuming a normal distribution. Shading in the histogram corresponds to INP activation temperature: $-15^{\circ} \mathrm{C}$ is dark gray, $-20^{\circ} \mathrm{C}$ is an intermediate gray, and $-25^{\circ} \mathrm{C}$ is light gray. As $2.5 \mu \mathrm{m}$ does not align with the size cut of a MOUDI stage, the fraction of INPs larger than $2.5 \mu \mathrm{m}$ was found by assuming that number concentration of INPs $1.8-3.2 \mu \mathrm{m}$ in size was uniformly distributed over that size range. As only one sample was available from the Labrador Sea, no uncertainty is reported.

2000; Diehl et al., 2002; Prenni et al., 2009; Iannone et al., 2011; Pummer et al., 2012; Huffman et al., 2013; Tobo et al., 2013; Haga et al., 2014; Wright et al., 2014), respectively. The sampling site at Saclay was also within $1 \mathrm{~km}$ of agricultural fields, an additional source of biological aerosols that may act as INPs (e.g., Lindow et al., 1982; Hirano et al., 1985; Georgakopoulos and Sands, 1992; Möhler et al., 2008; Bowers et al., 2011; Garcia et al., 2012; Haga et al., 2013; Morris et al., 2013; Hiranuma et al., 2015).

\subsection{INP size distributions}

Figure $3 \mathrm{a}$ shows the relative contribution of supermicron aerosol particles to the total measured INP population. Note that the same particle size range was not investigated at all locations with particles in the range of $0.10-0.18 \mu \mathrm{m}$ not being measured at Whistler Mountain or Amphitrite Point, and no uncertainty is reported for the Labrador Sea measurement as only a single sample was available. Averaging over all sampling locations with a 1 SD uncertainty, $91 \pm 9,79 \pm 17$, and $63 \pm 21 \%$ of INPs had an aerodynamic diameter $>1 \mu \mathrm{m}$ at ice activation temperatures of $-15,-20$, and $-25^{\circ} \mathrm{C}$, re- 


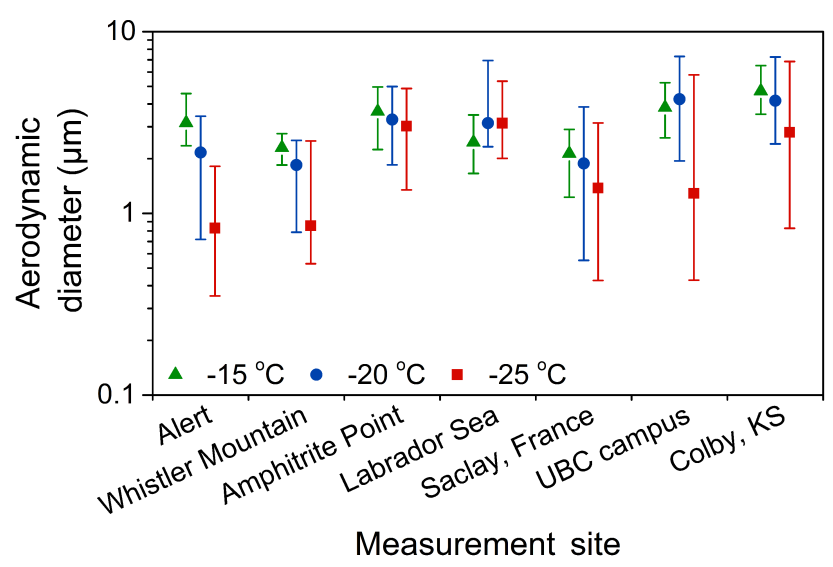

Figure 4. The median size of INPs at ice-activation temperatures of $-15^{\circ} \mathrm{C}$ (green), $-20^{\circ} \mathrm{C}$ (blue), and $-25^{\circ} \mathrm{C}$ (red) when averaged over all analyzed samples. Upper and lower uncertainties are the 75th and 25th percentiles, respectively.

spectively. At $-15^{\circ} \mathrm{C}$, the percentage of supermicron INPs ranged from $78 \%$ at Whistler Mountain up to $100 \%$ at the Labrador Sea and Colby sites. At lower temperatures, there was more variation between samples: at $-20^{\circ} \mathrm{C}$ the percentage of supermicron INPs ranged from $52 \%$ at Whistler Mountain to $100 \%$ over the Labrador Sea, and at $-25^{\circ} \mathrm{C}$ the percentage of supermicron INPs ranged from $39 \%$ at Whistler Mountain to $95 \%$ over the Labrador Sea.

Figure $3 \mathrm{~b}$ shows the fraction of INPs that are in the coarse mode, calculated by assuming that half of the INPs found in the 1.8-3.2 $\mu \mathrm{m}$ MOUDI size cut were larger than $2.5 \mu \mathrm{m}$ (i.e., INPs are uniformly distributed over this size range). Measurements of the total particle size distribution were not available at all locations to test this assumption. Furthermore, it is not known whether the INP size distribution follows the total particle size distribution a priori. Averaging over all sampling locations, the percentage of INPs in the coarse mode was $62 \pm 20,55 \pm 18$, and $42 \pm 17 \%$ (1 SD) at ice activation temperatures of $-15,-20$, and $-25^{\circ} \mathrm{C}$, respectively. The percentage of INPs in the coarse mode was found to range from $38 \%$ at Saclay to $91 \%$ in Colby at $-15^{\circ} \mathrm{C}$, from $26 \%$ at Whistler Mountain to $73 \%$ in Colby at $-20^{\circ} \mathrm{C}$, and from $20 \%$ at Alert to $64 \%$ at the Labrador Sea at $-25^{\circ} \mathrm{C}$. Despite great diversity in the studied locations, each had a significant contribution from coarse-mode particles to the measured INP population.

The median sizes of INPs at ice activation temperatures of $-15,-20$, and $-25^{\circ} \mathrm{C}$ are shown in Fig. 4 with the 25 th and 75th percentile values. At $-15^{\circ} \mathrm{C}$, the median INP size is relatively large at all locations, varying from $2.1 \mu \mathrm{m}$ at Saclay to $4.7 \mu \mathrm{m}$ at Colby with an average of $3.2 \pm 0.9 \mu \mathrm{m}$ (1 SD). As droplet freezing temperature decreased, the median INP size also decreased, with the exception of samples from the Labrador Sea and the UBC campus. At $-25^{\circ} \mathrm{C}$, the median size of INPs varied from $0.83 \mu \mathrm{m}$ at Alert to $3.1 \mu \mathrm{m}$ at the
Labrador Sea site with an average of $1.9 \pm 1.0 \mu \mathrm{m}$. The median size of the INPs was $>1 \mu \mathrm{m}$ in all cases with the exception of the Alert and Whistler Mountain sites at a freezing temperature of $-25^{\circ} \mathrm{C}$. Alert, in the polar tundra at high latitude, and Whistler Mountain, at high elevation and periodically in the free troposphere, are remote with fewer local sources of aerosols.

In Fig. 4, the difference between the 75th and 25th percentile sizes is relatively small at all locations at $-15^{\circ} \mathrm{C}$. A narrow INP size distribution at $-15^{\circ} \mathrm{C}$ is consistent with a single type or class of particles dominating freezing at this temperature. With decreasing temperature, the interquartile range significantly increased: the 75 th and 25 th percentile INP sizes decreased by an average factor of 1.2 and 3.7, respectively, between -15 and $-25^{\circ} \mathrm{C}$, corresponding to a $63 \%$ increase in the average interquartile range.

INP size distributions are further explored in Fig. 5, where the fraction of the measured INP number concentration found in each MOUDI size bin is shown. Colors on the red end of the scale illustrate that a large fraction of the INPs measured at a particular location belong to that particle size bin. Total INP number concentrations as a function of temperature are given in Fig. S1 and histograms of the INP size distributions are given in Figs. S2-S8. Figure 5a shows that most INPs active at $-15^{\circ} \mathrm{C}$ were $1-10 \mu \mathrm{m}$ in size. In particular, when averaged over all locations, $72 \%$ of the INPs active at $-15^{\circ} \mathrm{C}$ were between 1.8 and $5.6 \mu \mathrm{m}$. Furthermore, the major mode (i.e., the global maximum in a size distribution) was always larger than $1.8 \mu \mathrm{m}$. At lower freezing temperatures the INP size distributions broadened with increased contributions from smaller aerosol particles, evident by the more uniform intensity of Fig. $5 \mathrm{~b}$ and c. By $-25^{\circ} \mathrm{C}$, six of the seven locations had a submicron INP mode, and at Alert and Whistler Mountain this was the major mode. A general broadening of the INP size distribution with decreasing temperature would be expected if there were an increase in the number of particle types exhibiting ice activity with decreasing activation temperature.

Several previous studies have conducted size-resolved INP measurements. In most of these studies, the fraction of INPs larger than a given particle size was not reported, and in some cases the temperatures studied were different than in the current study. To better compare our data with these previous studies, we have used the literature data to calculate the fraction of INPs larger than either $1,1.2$, or $2.5 \mu \mathrm{m}$ at temperatures as close as possible to the freezing temperatures we used. Details of the calculations are presented in the Supplement, and the results of the calculations are summarized in Table 2.

Table 2 shows that in six out of the nine previous studies, a large fraction (16-100\%) of the INPs was found to be supermicron in size, consistent with the current study. Here the work of Rosinski et al. (1986) is considered as two separate studies given the change in the investigated mode of ice nucleation. Although the condensation and immersion freezing 
Table 2. Previous size-resolved INP measurements.

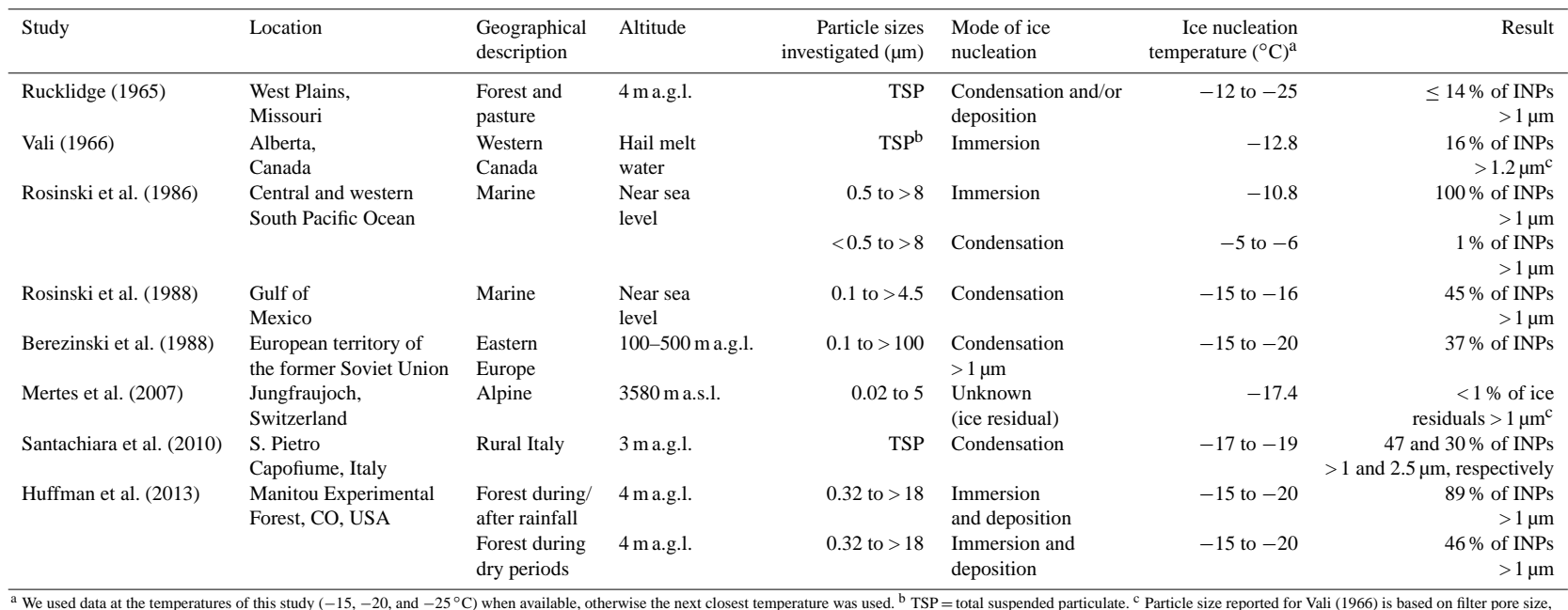

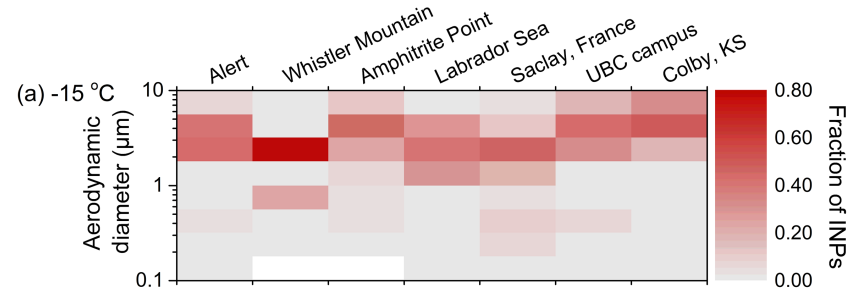

(b) -20

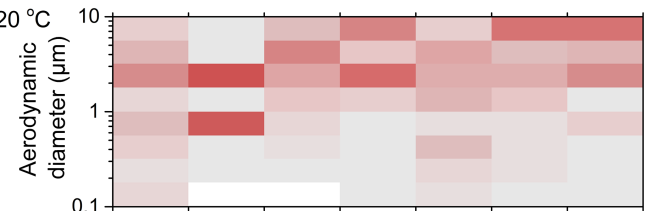

(c) -25

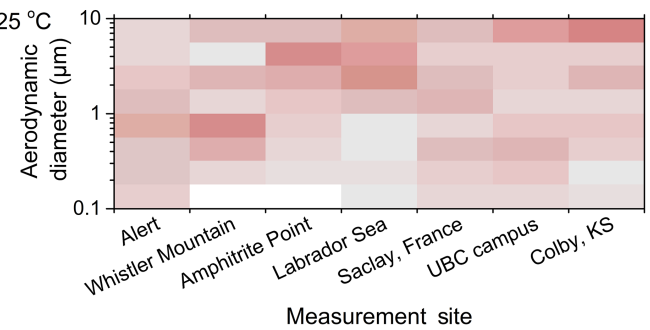

Figure 5. Fractional INP concentrations as a function of aerosol particle size, location, and activation temperature: (a) $-15^{\circ} \mathrm{C}$; (b) $-20^{\circ} \mathrm{C}$; and (c) $-25^{\circ} \mathrm{C}$. The color bar indicates the fraction of INPs measured in each particle size bin. Aerosol particle sizes correspond to the $50 \%$ cutoff aerodynamic diameters of the MOUDI stages (Marple et al., 1991). Missing sizes for the Whistler Mountain and Amphitrite Point sites are uncolored.

measurements reported in Rosinski et al. (1986) appear contradictory, it is important to note that the two freezing results for Rosinski et al. (1986) shown in Table 2 correspond to different temperature ranges (compare -5 to $-6^{\circ} \mathrm{C}$ for condensation and $-10.8^{\circ} \mathrm{C}$ for immersion freezing). One pos- sibility is that small particles dominated the INP population at the warmest temperatures while larger particles dominated the INP population at the colder temperatures investigated by Rosinski et al. (1986)

The ice nucleation efficiency of particles as a function of size have also been investigated in laboratory experiments (e.g., Lüönd et al., 2010; Archuleta et al., 2005; Welti et al., 2009). In general this work has shown that ice nucleation efficiency increases as particle size increases. Furthermore, several studies have investigated correlations between the concentrations of INPs and aerosol particles above a certain size (Richardson et al., 2007; DeMott et al., 2010; Chou et al., 2011; Field et al., 2012; Huffman et al., 2013; Prenni et al., 2013; Tobo et al., 2013; Ardon-Dryer and Levin, 2014; Jiang et al., 2014, 2015). For example, using data from a variety of field measurements DeMott et al. (2010) observed a correlation between INP concentrations and the concentration of aerosol particles $>0.5 \mu \mathrm{m}$, and Ardon-Dryer and Levin (2014) found that INP concentrations in Israel were better correlated to the concentration of aerosol particles 2.5$10 \mu \mathrm{m}$ in size than those $<2.5 \mu \mathrm{m}$. These results are also consistent with INPs being relatively large in size.

\section{Summary and conclusions}

INP number concentrations in the immersion mode as a function of size and droplet freezing temperature were determined at six locations across North America and one in Europe. INP number concentrations varied by as much as an order of magnitude between locations, and were generally found to be lowest at the remote sites of Alert and Whistler Mountain and highest at the agricultural sites of Colby and the suburban sites of Saclay and the UBC campus, consistent with previous studies. Several key findings indicate the potential importance of large INPs at ground level: (1) $91 \pm 9$ 
and $62 \pm 20 \%$ of INPs measured at $-15^{\circ} \mathrm{C}$ across all locations are supermicron or in the coarse mode, respectively; (2) at the lowest temperature analyzed, $-25^{\circ} \mathrm{C}, 63 \pm 21$ and $42 \pm 17 \%$ of INPs across all locations remained in the supermicron regime and coarse mode, respectively; (3) at $-15^{\circ} \mathrm{C}$, the median INP size was relatively large at all locations, varying from $2.1 \mu \mathrm{m}$ at Saclay to $4.7 \mu \mathrm{m}$ at Colby with an average of $3.2 \pm 0.9 \mu \mathrm{m}$; and (4) at $-25^{\circ} \mathrm{C}$, the median size INP varied from $0.83 \mu \mathrm{m}$ at Alert to $3.1 \mu \mathrm{m}$ above the Labrador Sea with an average of $1.9 \pm 1.0 \mu \mathrm{m}$.

Our measurements indicate that, when averaged over all studied locations and temperatures, $78 \pm 19$ and $53 \pm 20 \%$ of immersion-mode INPs may be missed if either supermicron particles or coarse-mode particles are not sampled at ground sites. As noted in Sect. 1, some instrumentation for measuring ambient INP number concentrations restricts the upper range of sampled aerosol particles. The data presented may be useful for estimating the fraction of INPs not measured with these instruments at ground sites and in different environments.

All measurements used in this study were conducted at ground level and, apart from those at Whistler Mountain, were also close to sea level. As the large contribution of supermicron and coarse-mode INPs to the overall INP population noted here may not necessarily hold for higher altitudes, additional size-resolved INP measurements as a function of altitude are needed. In obtaining such data, careful consideration will be needed toward sampling issues with aerosol inlets and transfer through sample lines on aircraft platforms. It can be anticipated that supermicron particle transfer will be strongly restricted without special inlets or care, and this may especially impact INP sampling.

A caveat to this study is that our measurements were confined to aerosol particle sizes greater than either 0.10 or $0.18 \mu \mathrm{m}$. If there were a significant contribution from INPs of smaller sizes (Vali, 1966; Schnell and Vali, 1973; Pummer et al., 2012; Augustin et al., 2013; Fröhlich-Nowoisky et al., 2015; O'Sullivan et al., 2015; Tong et al., 2015; Wilson et al., 2015), and these smaller sizes did not coagulate or get scavenged by larger particles, the values presented here would represent upper limits to the contribution of supermicron and coarse-mode particles to the total INP population. Additional studies exploring the relative atmospheric abundance of INPs $<0.10 \mu \mathrm{m}$ are necessary (Hader et al., 2014). Future studies of the size distribution of INPs should also include measurements of particle mixing state to determine whether particles are internally or externally mixed at the locations where the size distribution of INPs are being measured.

The Supplement related to this article is available online at doi:10.5194/acp-16-1637-2016-supplement.
Acknowledgements. The authors thank the three anonymous referees and G. Vali for helpful comments on the paper. The authors also thank R. B. Stull and R. Schigas for access to the UBC campus site and associated weather data, and L. A. Miller for assistance coordinating the measurements from the CCGS Amundsen. The authors also wish to thank Juniper Buller and Anton Horvath for access to the Whistler Mountain sampling site, and Freddie Lamm and the agricultural specialists at the Kansas State University Northwest Research Center for access to the Colby, KS sites, advice on harvesting time frames, and their help during harvesting. The sampling site at Amphitrite Point is jointly supported and maintained by Environment Canada, the British Columbia Ministry of Environment, and Metro Vancouver. We thank the Canadian Coast Guard and Department of Fisheries and Oceans staff from the Amphitrite Point site and the CCGS Amundsen for their help. The Natural Sciences and Engineering Research Council of Canada supported this research. K. J. Suski, P. J. DeMott, and T. C. J. Hill acknowledge support under US National Science Foundation grant AGS 1358495, which also provided support for measurements at the Colby, KS site. W. M. Lassar and K. M. Pierce acknowledge funding support through the University of Denver undergraduate research center. J. A. Huffman, W. M. Lassar and K. M. Pierce acknowledge the CEA/DAM/CBRN-E research programs and particularly D. Baisnée (CEA) for support in the intensive campaign and J. Sciare (CNRS) for the ancillary aerosol data.

Edited by: Y. Cheng

\section{References}

Al-Naimi, R. and Saunders, C. P. R.: Measurements of natural deposition and condensation-freezing ice nuclei with a continuous flow chamber, Atmos. Environ., 19, 1871-1882, doi:10.1016/0004-6981(85)90012-5, 1985.

Archuleta, C. M., DeMott, P. J., and Kreidenweis, S. M.: Ice nucleation by surrogates for atmospheric mineral dust and mineral dust/sulfate particles at cirrus temperatures, Atmos. Chem. Phys., 5, 2617-2634, doi:10.5194/acp-5-2617-2005, 2005.

Ardon-Dryer, K. and Levin, Z.: Ground-based measurements of immersion freezing in the eastern Mediterranean, Atmos. Chem. Phys., 14, 5217-5231, doi:10.5194/acp-14-5217-2014, 2014.

Ariya, P. A., Sun, J., Eltouny, N. A., Hudson, E. D., Hayes, C. T., and Kos, G.: Physical and chemical characterization of bioaerosols - Implications for nucleation processes, Int. Rev. Phys. Chem., 28, 1-32, doi:10.1080/01442350802597438, 2009.

Augustin, S., Wex, H., Niedermeier, D., Pummer, B., Grothe, H., Hartmann, S., Tomsche, L., Clauss, T., Voigtländer, J., Ignatius, K., and Stratmann, F.: Immersion freezing of birch pollen washing water, Atmos. Chem. Phys., 13, 10989-11003, doi:10.5194/acp-13-10989-2013, 2013.

Baisnée, D., Thibaudon, M., Baumier, R., McMeeking, G., Kok, G., O'Connor, D., Sodeau, J., Huffman, J. A., Lassar, W., Pierce, K., Gallagher, M., Crawford, I., Salines, G., and Sarda-Estève, R.: Simultaneous Real-time Fluorescence and Microscopy Measurements of Bioaerosols during the BIODETECT 2014 Campaign in Paris Area, AAAR 33rd Annual Conference, Orlando, Fl, October 20-24, 2014. 
Baker, M. B.: Cloud Microphysics and Climate, Science, 276, 1072-1078, doi:10.1126/science.276.5315.1072, 1997.

Baker, M. B. and Peter, T.: Small-scale cloud processes and climate, Nature, 451, 299-300, doi:10.1038/nature06594, 2008.

Bateman, A. P., Belassein, H., and Martin, S. T.: Impactor Apparatus for the Study of Particle Rebound: Relative Humidity and Capillary Forces, Aerosol Sci. Technol., 48, 42-52, doi:10.1080/02786826.2013.853866, 2014.

Berezinski, N. A., Stepanov, G. V., and Khorguani, V. G.: Iceforming activity of atmospheric aerosol particles of different sizes, Lecture Notes in Physics, edited by: Wagner, P. E. andVali, G., 309, 709-712, Springer, Heidelberg and Berlin, Germany, 1988.

Bigg, E. K.: Ice forming nuclei in the high Arctic, Tellus B, 48, 223-233, doi:10.3402/tellusb.v48i2.15888, 1996.

Bowers, R. M., Lauber, C. L., Wiedinmyer, C., Hamady, M., Hallar, A. G., Fall, R., Knight, R., and Fierer, N.: Characterization of Airborne Microbial Communities at a High-Elevation Site and Their Potential To Act as Atmospheric Ice Nuclei, Appl. Environ. Microbiol., 75, 5121-5130, doi:10.1128/AEM.00447-09, 2009.

Bowers, R. M., McLetchie, S., Knight, R., and Fierer, N.: Spatial variability in airborne bacterial communities across landuse types and their relationship to the bacterial communities of potential source environments, ISME J., 5, 601-612, doi:10.1038/ismej.2010.167, 2011.

Brooks, S. D., Suter, K., and Olivarez, L.: Effects of Chemical Aging on the Ice Nucleation Activity of Soot and Polycyclic Aromatic Hydrocarbon Aerosols, J. Phys. Chem. A, 118, 1003610047, doi:10.1021/jp508809y, 2014.

Burrows, S. M., Butler, T., Jöckel, P., Tost, H., Kerkweg, A., Pöschl, U., and Lawrence, M. G.: Bacteria in the global atmosphere - Part 2: Modeling of emissions and transport between different ecosystems, Atmos. Chem. Phys., 9, 9281-9297, doi:10.5194/acp-9-9281-2009, 2009.

Burrows, S. M., Hoose, C., Pöschl, U., and Lawrence, M. G.: Ice nuclei in marine air: biogenic particles or dust?, Atmos. Chem. Phys., 13, 245-267, doi:10.5194/acp-13-245-2013, 2013.

Chen, S.-C., Tsai, C.-J., Chen, H.-D., Huang, C.-Y., and Roam, G.-D.: The Influence of Relative Humidity on Nanoparticle Concentration and Particle Mass Distribution Measurements by the MOUDI, Aerosol Sci. Technol., 45, 596-603, doi:10.1080/02786826.2010.551557, 2011.

Chou, C., Stetzer, O., Weingartner, E., Jurányi, Z., Kanji, Z. A., and Lohmann, U.: Ice nuclei properties within a Saharan dust event at the Jungfraujoch in the Swiss Alps, Atmos. Chem. Phys., 11, 4725-4738, doi:10.5194/acp-11-4725-2011, 2011.

Clarke, A. D., Shinozuka, Y., Kapustin, V. N., Howell, S., Huebert, B., Doherty, S., Anderson, T., Covert, D., Anderson, J., Hua, X., Moore II, K. G., McNaughton, C., Carmichael, G., and Weber, R.: Size distributions and mixtures of dust and black carbon aerosol in Asian outflow: Physiochemistry and optical properties, J. Geophys. Res., 109, D15S09, doi:10.1029/2003JD004378, 2004

Cobbett, F. D., Steffen, A., Lawson, G., and Van Heyst, B. J.: GEM fluxes and atmospheric mercury concentrations (GEM, $\mathrm{RGM}$ and $\mathrm{Hg}^{p}$ ) in the Canadian Arctic at Alert, Nunavut, Canada (February-June 2005), Atmos. Environ., 41, 6527-6543, doi:10.1016/j.atmosenv.2007.04.033, 2007.
Conen, F., Henne, S., Morris, C. E., and Alewell, C.: Atmospheric ice nucleators active $=-12{ }^{\circ} \mathrm{C}$ can be quantified on PM10 filters, Atmos. Meas. Tech., 5, 321-327, doi:10.5194/amt-5-321-2012, 2012.

Corbin, J. C., Rehbein, P. J. G., Evans, G. J., and Abbatt, J. P. D.: Combustion particles as ice nuclei in an urban environment: Evidence from single-particle mass spectrometry, Atmos. Environ., 51, 286-292, doi:10.1016/j.atmosenv.2012.01.007, 2012.

Creamean, J. M., Suski, K. J., Rosenfeld, D., Cazorla, A., DeMott, P. J., Sullivan, R. C., White, A. B., Ralph, F. M., Minnis, P., Comstock, J. M., Tomlinson, J. M. and Prather, K. A. Dust and Biological Aerosols from the Sahara and Asia Influence Precipitation in the Western US, Science, 339, 1572-1578, doi:10.1126/science.1227279, 2013.

Cziczo, D. J., Froyd, K. D., Hoose, C., Jensen, E. J., Diao, M., Zondlo, M. A., Smith, J. B., Twohy, C. H., and Murphy, D. M.: Clarifying the Dominant Sources and Mechanisms of Cirrus Cloud Formation, Science, 340, 1320-1324, doi:10.1126/science.1234145, 2013.

Dahneke, B.: The capture of aerosol particles by surfaces, J. Colloid Interface Sci., 37, 342-353, doi:10.1016/0021-9797(71)90302X, 1971.

DeMott, P. J., Cziczo, D. J., Prenni, A. J., Murphy, D. M., Kreidenweis, S. M., Thomson, D. S., Borys, R., and Rogers, D. C.: Measurements of the concentration and composition of nuclei for cirrus formation, P. Natl. Acad. Sci. USA, 100, 14655-14660, doi:10.1073/pnas.2532677100, 2003.

DeMott, P. J., Möhler, O., Stetzer, O., Vali, G., Levin, Z., Petters, M. D., Murakami, M., Leisner, T., Bundke, U., Klein, H., Kanji, Z. A., Cotton, R., Jones, H., Benz, S., Brinkmann, M., Rzesanke, D., Saathoff, H., Nicolet, M., Saito, A., Nillius, B., Bingemer, H., Abbatt, J., Ardon, K., Ganor, E., Georgakopoulos, D. G., and Saunders, C.: Resurgence in ice nuclei measurement research, B. Am. Meteorol. Soc., 92, 1623-1635, doi:10.1175/2011BAMS3119.1, 2011.

DeMott, P. J., Prenni, A. J., Liu, X., Kreidenweis, S. M., Petters, M. D., Twohy, C. H., Richardson, M. S., Eidhammer, T., and Rogers, D. C.: Predicting global atmospheric ice nuclei distributions and their impacts on climate, P. Natl. Acad. Sci. USA, 107, 1121711222, doi:10.1073/pnas.0910818107, 2010.

DeMott, P. J., Rogers, D. C., Kreidenweis, S. M., Chen, Y., Twohy, C. H., Baumgardner, D., Heymsfield, A. J., and Chan, K. R.: The role of heterogeneous freezing nucleation in upper tropospheric clouds: Inferences from SUCCESS, Geophys. Res. Lett., 25, 1387-1390, doi:10.1029/97GL03779, 1998.

Després, V. R., Huffman, J. A., Burrows, S. M., Hoose, C., Safatov, A. S., Buryak, G., Fröhlich-Nowoisky, J., Elbert, W., Andreae, M. O., Pöschl, U., and Jaenicke, R.: Primary biological aerosol particles in the atmosphere: a review, Tellus B, 64, 15598, doi:10.3402/tellusb.v64i0.15598, 2012.

Diehl, K., Matthias-Maser, S., Jaenicke, R. ,and Mitra, S. K.: The ice nucleating ability of pollen: Part II. Laboratory studies in immersion and contact freezing modes, Atmos. Res., 61, 125-133, doi:10.1016/S0169-8095(01)00132-6, 2002.

Draxler, R. R. and Rolph, G. D.: HYSPLIT (HYbrid SingleParticle Lagrangian Integrated Trajectory) Model access via NOAA ARL READY Website, NOAA Air Resources Laboratory, Silver Spring, MD, available at: http://ready.arl.noaa.gov/ HYSPLIT.php, last access: 27 May 2014. 
Ebert, M., Worringen, A., Benker, N., Mertes, S., Weingartner, E., and Weinbruch, S.: Chemical composition and mixing-state of ice residuals sampled within mixed phase clouds, Atmos. Chem. Phys., 11, 2805-2816, doi:10.5194/acp-11-2805-2011, 2011.

Eidhammer, T., DeMott, P. J., Prenni, A. J., Petters, M. D., Twohy, C. H., Rogers, D. C., Stith, J., Heymsfield, A., Wang, Z., Pratt, K. A., Prather, K. A., Murphy, S. M., Seinfeld, J. H., Subramanian, R., and Kreidenweis, S. M.: Ice Initiation by Aerosol Particles: Measured and Predicted Ice Nuclei Concentrations versus Measured Ice Crystal Concentrations in an Orographic Wave Cloud, J. Atmos. Sci., 67, 2417-2436, doi:10.1175/2010JAS3266.1, 2010.

Elbert, W., Taylor, P. E., Andreae, M. O., and Pöschl, U.: Contribution of fungi to primary biogenic aerosols in the atmosphere: wet and dry discharged spores, carbohydrates, and inorganic ions, Atmos. Chem. Phys., 7, 4569-4588, doi:10.5194/acp-7-4569-2007, 2007.

Fang, C. P., McMurry, P. H., Marple, V. A., and Rubow, K. L.: Effect of Flow-induced Relative Humidity Changes on Size Cuts for Sulfuric Acid Droplets in the Microorifice Uniform Deposit Impactor (MOUDI), Aerosol Sci. Technol., 14, 266-277, doi:10.1080/02786829108959489, 1991.

Field, P. R., Heymsfield, A. J., Shipway, B. J., DeMott, P. J., Pratt, K. A., Rogers, D. C., Stith, J., and Prather, K. A.: Ice in Clouds Experiment-Layer Clouds, Part II: Testing Characteristics of Heterogeneous Ice Formation in Lee Wave Clouds, J. Atmos. Sci., 69, 1066-1079, doi:10.1175/JAS-D-11-026.1, 2012.

Fountain, A. G. and Ohtake, T.: Concentrations and Source Areas of Ice Nuclei in the Alaskan Atmosphere, J. Clim. Appl. Meteorol., 24, 377-382, 1985.

Friedman, B., Kulkarni, G., Beránek, J., Zelenyuk, A., Thornton, J. A., and Cziczo, D. J.: Ice nucleation and droplet formation by bare and coated soot particles, J. Geophys. Res., 116, D17203, doi:10.1029/2011JD015999, 2011.

Fröhlich-Nowoisky, J., Hill, T. C. J., Pummer, B. G., Yordanova, P., Franc, G. D., and Pöschl, U.: Ice nucleation activity in the widespread soil fungus Mortierella alpina, Biogeosciences, 12, 1057-1071, doi:10.5194/bg-12-1057-2015, 2015.

Gallagher, J. P., McKendry, I. G., Macdonald, A. M., and Leaitch, W. R.: Seasonal and Diurnal Variations in Aerosol Concentration on Whistler Mountain: Boundary Layer Influence and SynopticScale Controls, J. Appl. Meteorol. Climatol., 50, 2210-2222, doi:10.1175/JAMC-D-11-028.1, 2011.

Garcia, E., Hill, T. C. J., Prenni, A. J., DeMott, P. J., Franc, G. D., and Kreidenweis, S. M.: Biogenic ice nuclei in boundary layer air over two U.S. High Plains agricultural regions, J. Geophys. Res., 117, D18209, doi:10.1029/2012JD018343, 2012.

Georgakopoulos, D. G. and Sands, D. C.: Epiphytic populations of Pseudomonas syringae on barley, Can. J. Microbiol., 38, 111114, doi:10.1139/m92-018, 1992.

Graham, B., Guyon, P., Maenhaut, W., Taylor, P. E., Ebert, M., Matthias-Maser, S., Mayol-Bracero, O. L., Godoi, R. H. M., Artaxo, P., Meixner, F. X., Moura, M. A. L., Rocha, C. H. E. D., Van Grieken, R., Glovsky, M. M., Flagan, R. C., and Andreae, M. O.: Composition and diurnal variability of the natural Amazonian aerosol, J. Geophys. Res., 108, 4765, doi:10.1029/2003JD004049, 2003.
Hader, J. D., Wright, T. P., and Petters, M. D.: Contribution of pollen to atmospheric ice nuclei concentrations, Atmos. Chem. Phys., 14, 5433-5449, doi:10.5194/acp-14-5433-2014, 2014.

Haga, D. I., Burrows, S. M., Iannone, R., Wheeler, M. J., Mason, R. H., Chen, J., P olishchuk, E. A., Pöschl, U., and Bertram, A. K.: Ice nucleation by fungal spores from the classes Agaricomycetes, Ustilaginomycetes, and Eurotiomycetes, and the effect on the atmospheric transport of these spores, Atmos. Chem. Phys., 14, 8611-8630, doi:10.5194/acp-14-8611-2014, 2014.

Haga, D. I., Iannone, R., Wheeler, M. J., Mason, R., Polishchuk, E. A., Fetch Jr., T., van der Kamp, B. J., McKendry, I. G., and Bertram, A. K.: Ice nucleation properties of rust and bunt fungal spores and their transport to high altitudes, where they can cause heterogeneous freezing, J. Geophys. Res.-Atmos., 118, 7260 7272, doi:10.1002/jgrd.50556, 2013.

Hirano, S. S., Baker, L. S., and Upper, C. D.: Ice nucleation temperature of individual leaves in relation to population sizes of ice nucleation active bacteria and frost injury, Plant Physiol., 77, 259-265, doi:10.1104/pp.77.2.259, 1985.

Hirano, S. S. and Upper, C. D.: Bacteria in the leaf ecosystem with emphasis on Pseudomonas syringae - a pathogen, ice nucleus, and epiphyte, Microbiol. Mol. Biol. R., 64, 624-653, doi:10.1128/MMBR.64.3.624-653.2000, 2000.

Hiranuma, N., Möhler, O., Yamashita, K., Tajiri, T., Saito, A., Kiselev, A., Hoffmann, N., Hoose, C., Jantsch, E., Koop, T., and Murakami, M.: Ice nucleation by cellulose and its potential contribution to ice formation in clouds, Nat. Geosci., 8, 273-277, doi:10.1038/ngeo2374, 2015.

Hobbs, P. V and Locatelli, J. D.: Ice Nucleus Measurements at Three Sites in Western Washington, J. Atmos. Sci., 27, 90-100, 1970.

Hoose, C., Kristjánsson, J. E., and Burrows, S. M.: How important is biological ice nucleation in clouds on a global scale?, Environ. Res. Lett., 5, 024009, doi:10.1088/1748-9326/5/2/024009, 2010a.

Hoose, C., Kristjánsson, J. E., Chen, J.-P., and Hazra, A.: A Classical-Theory-Based Parameterization of Heterogeneous Ice Nucleation by Mineral Dust, Soot, and Biological Particles in a Global Climate Model, J. Atmos. Sci., 67, 2483-2503, doi:10.1175/2010JAS3425.1, 2010b.

Hoose, C. and Möhler, O.: Heterogeneous ice nucleation on atmospheric aerosols: a review of results from laboratory experiments, Atmos. Chem. Phys., 12, 9817-9854, doi:10.5194/acp-12-98172012, 2012.

Hoyle, C. R., Pinti, V., Welti, A., Zobrist, B., Marcolli, C., Luo, B., Höskuldsson, Á., Mattsson, H. B., Stetzer, O., Thorsteinsson, T., Larsen, G., and Peter, T.: Ice nucleation properties of volcanic ash from Eyjafjallajökull, Atmos. Chem. Phys., 11, 9911-9926, doi:10.5194/acp-11-9911-2011, 2011.

Huffman, J. A., Prenni, A. J., DeMott, P. J., Pöhlker, C., Mason, R. H., Robinson, N. H., Fröhlich-Nowoisky, J., Tobo, Y., Després, V. R., Garcia, E., Gochis, D. J., Harris, E., Müller-Germann, I., Ruzene, C., Schmer, B., Sinha, B., Day, D. A., Andreae, M. O., Jimenez, J. L., Gallagher, M., Kreidenweis, S. M., Bertram, A. K., and Pöschl, U.: High concentrations of biological aerosol particles and ice nuclei during and after rain, Atmos. Chem. Phys., 13, 6151-6164, doi:10.5194/acp-13-6151-2013, 2013.

Huffman, J. A., Sinha, B., Garland, R. M., Snee-Pollmann, A., Gunthe, S. S., Artaxo, P., Martin, S. T., Andreae, M. O., and 
Pöschl, U.: Size distributions and temporal variations of biological aerosol particles in the Amazon rainforest characterized by microscopy and real-time UV-APS fluorescence techniques during AMAZE-08, Atmos. Chem. Phys., 12, 11997-12019, doi:10.5194/acp-12-11997-2012, 2012.

Iannone, R., Chernoff, D. I., Pringle, A., Martin, S. T., and Bertram, A. K.: The ice nucleation ability of one of the most abundant types of fungal spores found in the atmosphere, Atmos. Chem. Phys., 11, 1191-1201, doi:10.5194/acp-11-1191-2011, 2011.

Jiang, H., Yin, Y., Su, H., Shan, Y., and Gao, R.: The characteristics of atmospheric ice nuclei measured at the top of Huangshan (the Yellow Mountains) in Southeast China using a newly built static vacuum water vapor diffusion chamber, Atmos. Res., 153, 200208, doi:10.1016/j.atmosres.2014.08.015, 2015.

Jiang, H., Yin, Y., Yang, L., Yang, S., Su, H., and Chen, K.: The characteristics of atmospheric ice nuclei measured at different altitudes in the Huangshan Mountains in Southeast China, Adv. Atmos. Sci., 31, 396-406, doi:10.1007/s00376-013-3048-5, 2014.

Kieft, T. L. and Ruscetti, T.: Characterization of biological ice nuclei from a lichen, J. Bacteriol., 172, 3519-3523, 1990.

Knopf, D. A., Alpert, P. A., Wang, B., O’Brien, R. E., Kelly, S. T., Laskin, A., Gilles, M. K., and Moffet, R. C.: Microspectroscopic imaging and characterization of individually identified ice nucleating particles from a case field study, J. Geophys. Res.-Atmos., 119, 10365-10381, doi:10.1002/2014JD021866, 2014.

Knopf, D. A., Wang, B., Laskin, A., Moffet, R. C., and Gilles, M. K.: Heterogeneous nucleation of ice on anthropogenic organic particles collected in Mexico City, Geophys. Res. Lett., 37, L11803, doi:10.1029/2010GL043362, 2010.

Koop, T., Luo, B., Biermann, U. M., Crutzen, P. J., and Peter, T.: Freezing of $\mathrm{HNO}_{3} / \mathrm{H}_{2} \mathrm{SO}_{4} / \mathrm{H}_{2} \mathrm{O}$ solutions at stratospheric temperatures: Nucleation statistics and experiments, J. Phys. Chem. A, 101, 1117-1133, doi:10.1021/jp9626531, 1997.

Koop, T., Ng, H. P., Molina, L. T., and Molina, M. J.: A New Optical Technique to Study Aerosol Phase Transitions: The Nucleation of Ice from $\mathrm{H}_{2} \mathrm{SO}_{4}$ Aerosols, J. Phys. Chem. A, 102, 8924-8931, doi:10.1021/jp9828078, 1998.

Lawson, D. R.: Impaction surface coatings intercomparison and measurements with cascade impactors, Atmos. Environ., 14, 195-199, doi:10.1016/0004-6981(80)90278-4, 1980.

Lindow, S. E., Arny, D. C., and Upper, C. D.: Bacterial ice nucleation: a factor in frost injury to plants, Plant Physiol., 70, 10841089, doi:10.1104/pp.70.4.1084, 1982.

Lohmann, U. and Feichter, J.: Global indirect aerosol effects: a review, Atmos. Chem. Phys., 5, 715-737, doi:10.5194/acp-5-7152005, 2005.

Lüönd, F., Stetzer, O., Welti, A., and Lohmann, U.: Experimental study on the ice nucleation ability of size-selected kaolinite particles in the immersion mode, J. Geophys. Res., 115, D14201, doi:10.1029/2009JD012959, 2010.

Macdonald, A. M., Anlauf, K. G., Leaitch, W. R., Chan, E., and Tarasick, D. W.: Interannual variability of ozone and carbon monoxide at the Whistler high elevation site: 2002-2006, Atmos. Chem. Phys., 11, 11431-11446, doi:10.5194/acp-1111431-2011, 2011.

Marple, V. A., Rubow, K. L., and Behm, S. M.: A Microorifice Uniform Deposit Impactor (MOUDI): Description, Calibration, and Use, Aerosol Sci. Technol., 14, 434-446, doi:10.1080/02786829108959504, 1991.
Mason, R. H., Chou, C., McCluskey, C. S., Levin, E. J. T., Schiller, C. L., Hill, T. C. J., Huffman, J. A., DeMott, P. J., and Bertram, A. K.: The micro-orifice uniform deposit impactordroplet freezing technique (MOUDI-DFT) for measuring concentrations of ice nucleating particles as a function of size: improvements and initial validation, Atmos. Meas. Tech., 8, 24492462, doi:10.5194/amt-8-2449-2015, 2015a.

Mason, R. H., Si, M., Li, J., Chou, C., Dickie, R., Toom-Sauntry, D., Pöhlker, C., Yakobi-Hancock, J. D., Ladino, L. A., Jones, K., Leaitch, W. R., Schiller, C. L., Abbatt, J. P. D., Huffman, J. A., and Bertram, A. K.: Ice nucleating particles at a coastal marine boundary layer site: correlations with aerosol type and meteorological conditions, Atmos. Chem. Phys., 15, 12547-12566, doi:10.5194/acp-15-12547-2015, 2015b.

McCluskey, C. S., DeMott, P. J., Prenni, A. J., Levin, E. J. T., McMeeking, G. R., Sullivan, A. P., Hill, T. C. J., Nakao, S., Carrico, C. M., and Kreidenweis, S. M.: Characteristics of atmospheric ice nucleating particles associated with biomass burning in the US: Prescribed burns and wildfires, J. Geophys. Res.Atmos., 119, 10458-10470, doi:10.1002/2014JD021980, 2014.

McKendry, I. G., Christensen, E., Schiller, C. L., Vingarzan, R., Macdonald, A. M., and Li, Y.: Low Ozone Episodes at Amphitrite Point Marine Boundary Layer Observatory, British Columbia, Canada, Atmos. Ocean, 52, 271-280, doi:10.1080/07055900.2014.910164, 2014.

Mertes, S., Verheggen, B., Walter, S., Connolly, P., Ebert, M., Schneider, J., Bower, K. N., Cozic, J., Weinbruch, S., Baltensperger, U., and Weingartner, E.: Counterflow Virtual Impactor Based Collection of Small Ice Particles in Mixed-Phase Clouds for the Physico-Chemical Characterization of Tropospheric Ice Nuclei: Sampler Description and First Case Study, Aerosol Sci. Technol., 41, 848-864, doi:10.1080/02786820701501881, 2007.

Möhler, O., DeMott, P. J., Vali, G., and Levin, Z.: Microbiology and atmospheric processes: the role of biological particles in cloud physics, Biogeosciences, 4, 1059-1071, doi:10.5194/bg-4-10592007, 2007.

Möhler, O., Georgakopoulos, D. G., Morris, C. E., Benz, S., Ebert, V., Hunsmann, S., Saathoff, H., Schnaiter, M., and Wagner, R.: Heterogeneous ice nucleation activity of bacteria: new laboratory experiments at simulated cloud conditions, Biogeosciences, 5, 1425-1435, doi:10.5194/bg-5-1425-2008, 2008.

Morris, C. E., Georgakopoulos, D. G. and Sands, D. C.: Ice nucleation active bacteria and their potential role in precipitation, J. Phys. IV, 121, 87-103, doi:10.1051/jp4:2004121004, 2004.

Morris, C. E., Sands, D. C., Glaux, C., Samsatly, J., Asaad, S., Moukahel, A. R., Gonçalves, F. L. T., and Bigg, E. K.: Urediospores of rust fungi are ice nucleation active at $>-10^{\circ} \mathrm{C}$ and harbor ice nucleation active bacteria, Atmos. Chem. Phys., 13, 4223-4233, doi:10.5194/acp-13-4223-2013, 2013.

Murray, B. J., Broadley, S. L., Wilson, T. W., Atkinson, J. D., and Wills, R. H.: Heterogeneous freezing of water droplets containing kaolinite particles, Atmos. Chem. Phys., 11, 4191-4207, doi:10.5194/acp-11-4191-2011, 2011.

Murray, B. J., O'Sullivan, D., Atkinson, J. D., and Webb, M. E.: Ice nucleation by particles immersed in supercooled cloud droplets, Chem. Soc. Rev., 41, 6519-6554, doi:10.1039/c2cs35200a, 2012. 
O’Sullivan, D., Murray, B. J., Ross, J. F., Whale, T. F., Price, H. C., Atkinson, J. D., Umo, N. S., and Webb, M. E.: The relevance of nanoscale biological fragments for ice nucleation in clouds, Sci. Rep., 5, 8082, doi:10.1038/srep08082, 2015.

Pratt, K. A., DeMott, P. J., French, J. R., Wang, Z., Westphal, D. L., Heymsfield, A. J., Twohy, C. H., Prenni, A. J., and Prather, K. A.: In situ detection of biological particles in cloud ice-crystals, Nat. Geosci., 2, 398-401, doi:10.1038/ngeo521, 2009.

Prenni, A. J., Harrington, J. Y., Tjernström, M., DeMott, P. J., Avramov, A., Long, C. N., Kreidenweis, S. M., Olsson, P. Q., and Verlinde, J.: Can Ice-Nucleating Aerosols Affect Arctic Seasonal Climate?, B. Am. Meteorol. Soc., 88, 541-550, doi:10.1175/BAMS-88-4-541, 2007.

Prenni, A. J., Petters, M. D., Kreidenweis, S. M., Heald, C. L., Martin, S. T., Artaxo, P., Garland, R. M., Wollny, A. G., and Pöschl, U.: Relative roles of biogenic emissions and Saharan dust as ice nuclei in the Amazon basin, Nat. Geosci., 2, 402-405, doi:10.1038/ngeo517, 2009.

Prenni, A. J., Tobo, Y., Garcia, E., DeMott, P. J., Huffman, J. A., McCluskey, C. S., Kreidenweis, S. M., Prenni, J. E., Pöhlker, C., and Pöschl, U.: The impact of rain on ice nuclei populations at a forested site in Colorado, Geophys. Res. Lett., 40, 227-231, doi:10.1029/2012GL053953, 2013.

Pummer, B. G., Bauer, H., Bernardi, J., Bleicher, S., and Grothe, H.: Suspendable macromolecules are responsible for ice nucleation activity of birch and conifer pollen, Atmos. Chem. Phys., 12, 2541-2550, doi:10.5194/acp-12-2541-2012, 2012.

Richard, C., Martin, J.-G., and Pouleur, S.: Ice nucleation activity identified in some phytopathogenic Fusarium species, Phytoprotection, 77, 83-92, doi:10.7202/706104ar, 1996.

Richardson, M. S., DeMott, P. J., Kreidenweis, S. M., Cziczo, D. J., Dunlea, E. J., Jimenez, J. L., Thomson, D. S., Ashbaugh, L. L., Borys, R. D., Westphal, D. L., Casuccio, G. S. and Lersch, T. L.: Measurements of heterogeneous ice nuclei in the western United States in springtime and their relation to aerosol characteristics, J. Geophys. Res., 112, D02209, doi:10.1029/2006JD007500, 2007.

Rogers, D. C., DeMott, P. J., and Kreidenweis, S. M.: Airborne measurements of tropospheric ice-nucleating aerosol particles in the Arctic spring, J. Geophys. Res., 106, 15053-15063, doi:10.1029/2000JD900790, 2001a.

Rogers, D. C., DeMott, P. J., Kreidenweis, S. M., and Chen, Y.: Measurements of ice nucleating aerosols during SUCCESS, Geophys. Res. Lett., 25, 1383-1386, doi:10.1029/97GL03478, 1998.

Rogers, D. C., DeMott, P. J., Kreidenweis, S. M., and Chen, Y.: A continuous-flow diffusion chamber for airborne measurements of ice nuclei, J. Atmos. Ocean. Technol., 18, 725-741, $2001 \mathrm{~b}$.

Rosinski, J., Haagenson, P. L., Nagamoto, C. T., and Parungo, F.: Ice-forming nuclei of maritime origin, J. Aerosol Sci., 17, 2346, doi:10.1016/0021-8502(86)90004-2, 1986.

Rosinski, J., Haagenson, P. L., Nagamoto, C. T., Quintana, B., Parungo, F., and Hoyt, S. D.: Ice-forming nuclei in air masses over the Gulf of Mexico, J. Aerosol Sci., 19, 539-551, doi:10.1016/0021-8502(88)90206-6, 1988.

Rosinski, J., Nagamoto, C. T., and Zhou, M. Y.: Ice-forming nuclei over the East China Sea, Atmos. Res., 36, 95-105, doi:10.1016/0169-8095(94)00029-D, 1995.
Rucklidge, J.: The Examination by Electron Microscope of Ice Crystal Nuclei from Cloud Chamber Experiments, J. Atmos. Sci., 22, 301-308, 1965.

Santachiara, G., Di Matteo, L., Prodi, F., and Belosi, F.: Atmospheric particles acting as Ice Forming Nuclei in different size ranges, Atmos. Res., 96, 266-272, doi:10.1016/j.atmosres.2009.08.004, 2010.

Sarda-Estève, R., Huffman, J. A., Gallagher, M., Thibaudon, M., Baisnee, D., Baumier, R., McKeening, G., Kok, G., Sodeau, J., O'Connor, D., Crawford, I., Flynn, M., Saari, S., Poeschl, U., Gros, V., Favez, O., Amodeo, T., Sciare, J., Bonnaire, N., Lassar, W., Pierce, K., Chou, C., Bertram, A., Salines, G., Roux, J.-M., Nadal, M. H., Bossuet, C., and Olmedo, L.: BIODETECT 2014 campaign in Paris area: overview of the experimental strategy and preliminary results, AAAR 33rd Annual Conference, Orlando, Fl, October 20-24, 2014.

Saukko, E., Kuuluvainen, H., and Virtanen, A.: A method to resolve the phase state of aerosol particles, Atmos. Meas. Tech., 5, 259265, doi:10.5194/amt-5-259-2012, 2012.

Schnell, R. C.: Ice Nuclei in Seawater, Fog Water and Marine Air off the Coast of Nova Scotia: Summer 1975, J. Atmos. Sci., 34, 1299-1305, 1977.

Schnell, R. C. and Vali, G.: World-wide source of leaf-derived freezing nuclei, Nature, 246, 212-213, doi:10.1038/246212a0, 1973.

Schwarz, J. P., Gao, R. S., Perring, A. E., Spackman, J. R. and Fahey, D. W.: Black carbon aerosol size in snow, Sci. Rep., 3, 1356, doi:10.1038/srep01356, 2013.

Schwarz, J. P., Gao, R. S., Spackman, J. R., Watts, L. A., Thomson, D. S., Fahey, D. W., Ryerson, T. B., Peischl, J., Holloway, J. S., Trainer, M., Frost, G. J., Baynard, T., Lack, D. A., de Gouw, J. A., Warneke, C., and Del Negro, L. A.: Measurement of the mixing state, mass, and optical size of individual black carbon particles in urban and biomass burning emissions, Geophys. Res. Lett., 35, L13810, doi:10.1029/2008GL033968, 2008.

Sesartic, A. and Dallafior, T. N.: Global fungal spore emissions, review and synthesis of literature data, Biogeosciences, 8, 11811192, doi:10.5194/bg-8-1181-2011, 2011.

Sesartic, A., Lohmann, U., and Storelvmo, T.: Modelling the impact of fungal spore ice nuclei on clouds and precipitation, Environ. Res. Lett., 8, 014029, doi:10.1088/1748-9326/8/1/014029, 2013.

Spracklen, D. V. and Heald, C. L.: The contribution of fungal spores and bacteria to regional and global aerosol number and ice nucleation immersion freezing rates, Atmos. Chem. Phys., 14, 90519059, doi:10.5194/acp-14-9051-2014, 2014.

Stein, S. W., Turpin, B. J., Cai, X., Huang, P.-F., and McMurray, P. H.: Measurements of relative humidity-dependent bounce and density for atmospheric particles using the DMA-impactor technique, Atmos. Environ., 28, 1739-1746, doi:10.1016/13522310(94)90136-8, 1994.

Szyrmer, W. and Zawadzki, I.: Biogenic and anthropogenic sources of ice-forming nuclei: A review, B. Am. Meteorol. Soc., 78, 209228, 1997.

Tobo, Y., Prenni, A. J., DeMott, P. J., Huffman, J. A., McCluskey, C. S., Tian, G., Pöhlker, C., Pöschl, U., and Kreidenweis, S. M.: Biological aerosol particles as a key determinant of ice nuclei populations in a forest ecosystem, J. Geophys. Res., 118, 1010010110, doi:10.1002/jgrd.50801, 2013.

Tong, H.-J., Ouyang, B., Nikolovski, N., Lienhard, D. M., Pope, F. D., and Kalberer, M.: A new electrodynamic balance (EDB) de- 
sign for low-temperature studies: application to immersion freezing of pollen extract bioaerosols, Atmos. Meas. Tech., 8, 11831195, doi:10.5194/amt-8-1183-2015, 2015.

Vali, G.: Sizes of Atmospheric Ice Nuclei, Nature, 212, 384-385, doi:10.1038/212384a0, 1966

Vali, G.: Quantitative Evaluation of Experimental Results on the Heterogeneous Freezing Nucleation of Supercooled Liquids, J. Atmos. Sci., 28, 402-409, 1971.

Vali, G.: Interpretation of freezing nucleation experiments: singular and stochastic; sites and surfaces, Atmos. Chem. Phys., 14, 5271-5294, doi:10.5194/acp-14-5271-2014, 2014.

Vali, G., Christensen, M., Fresh, R. W., Galyan, E. L., Maki, L. R., and Schnell, R. C.: Biogenic Ice Nuclei. Part II: Bacterial Sources, J. Atmos. Sci., 33, 1565-1570, 1976.

Vali, G., DeMott, P. J., Möhler, O., and Whale, T. F.: Technical Note: A proposal for ice nucleation terminology, Atmos. Chem. Phys., 15, 10263-10270, doi:10.5194/acp-15-10263-2015, 2015.

Vasiliou, J. G., Sorensen, D., and McMurry, P. H.: Sampling at controlled relative humidity with a cascade impactor, Atmos. Environ., 33, 1049-1056, doi:10.1016/S1352-2310(98)00323-9, 1999.

Wang, B., Laskin, A., Roedel, T., Gilles, M. K., Moffet, R. C., Tivanski, A. V., and Knopf, D. A.: Heterogeneous ice nucleation and water uptake by field-collected atmospheric particles below 273 K, J. Geophys. Res., 117, D00V19, doi:10.1029/2012JD017446, 2012.

Welti, A., Lüönd, F., Kanji, Z. A., Stetzer, O., and Lohmann, U.: Time dependence of immersion freezing: an experimental study on size selected kaolinite particles, Atmos. Chem. Phys., 12, 9893-9907, doi:10.5194/acp-12-9893-2012, 2012.

Welti, A., Lüönd, F., Stetzer, O., and Lohmann, U.: Influence of particle size on the ice nucleating ability of mineral dusts, Atmos. Chem. Phys., 9, 6705-6715, doi:10.5194/acp-9-6705-2009, 2009.

Wheeler, M. J., Mason, R. H., Steunenberg, K., Wagstaff, M., Chou, C., and Bertram, A. K.: Immersion Freezing of Supermicron Mineral Dust Particles: Freezing Results, Testing Different Schemes for Describing Ice Nucleation, and Ice Nucleation Active Site Densities, J. Phys. Chem. A, 119, 4358-4372, doi:10.1021/jp507875q, 2015.
Wilkinson, D. M., Koumoutsaris, S., Mitchell, E. A. D., and Bey, I.: Modelling the effect of size on the aerial dispersal of microorganisms, J. Biogeogr., 39, 89-97, doi:10.1111/j.13652699.2011.02569.x, 2011.

Wilson, T. W., Ladino, L. A., Alpert, P. A., Breckels, M. N., Brooks, I. M., Browse, J., Burrows, S. M., Carslaw, K. S., Huffman, J. A., Judd, C., Kilthau, W. P., Mason, R. H., McFiggans, G., Miller, L. A., Najera, J., Polishchuk, E., Rae, S., Schiller, C. L., Si, M., Vergara Temprado, J., Whale, T. F., Wong, J. P. S., Wurl, O., Yakobi-Hancock, J. D., Abbatt, J. P. D., Aller, J. Y., Bertram, A. K., Knopf, D. A., and Murray, B. J.: A marine biogenic source of atmospheric ice nucleating particles, 525, 234238, doi:10.1038/nature14986, 2015.

Winkler, P.: Relative humidity and the adhesion of atmospheric particles to the plates of impactors, J. Aerosol Sci., 5, 235-240, doi:10.1016/0021-8502(74)90058-5, 1974.

Wright, T. P., Hader, J. D., McMeeking, G. R., and Petters, M. D.: High Relative Humidity as a Trigger for Widespread Release of Ice Nuclei, Aerosol Sci. Technol., 48, 1-5, doi:10.1080/02786826.2014.968244, 2014.

Wright, T. P. and Petters, M. D.: The role of time in heterogeneous freezing nucleation, J. Geophys. Res.-Atmos., 118, 3731-3743, doi:10.1002/jgrd.50365, 2013.

Wright, T. P., Petters, M. D., Hader, J. D., Morton, T., and Holder, A. L.: Minimal cooling rate dependence of ice nuclei activity in the immersion mode, J. Geophys. Res.-Atmos., 118, 10535-10543, doi:10.1002/jgrd.50810, 2013.

Yakobi-Hancock, J. D., Ladino, L. A., and Abbattt, J. P. D.: Review of recent developments and shortcomings in the characterization of potential atmospheric ice nuclei: focus on the tropics, Rev. Ciencias, 17, 15-34, 2013.

Yakobi-Hancock, J. D., Ladino, L. A., Bertram, A. K., Huffman, J. A., Jones, K., Leaitch, W. R., Mason, R. H., Schiller, C. L., Toom-Sauntry, D., Wong, J. P. S., and Abbatt, J. P. D.: CCN activity of size-selected aerosol at a Pacific coastal location, Atmos. Chem. Phys., 14, 12307-12317, doi:10.5194/acp14-12307-2014, 2014. 